Sahl DERSHAWI

Dr. Öğr. Üy., Karabük Üniversitesi, İlahiyat Fakültesi Dr., Karabuk University, Theology Faculty Orcid ID: 0000-0002-5339-6542

Sahlder@hotmail.com

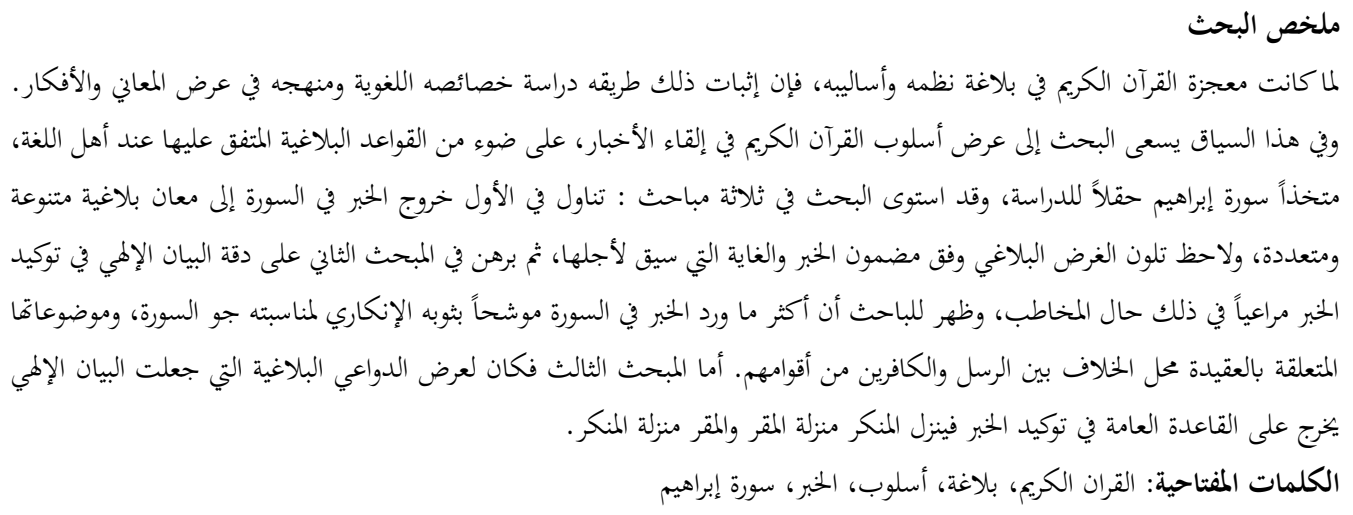

\title{
İbrahim Suresinde Haber Üslubunun Belagati
}

Öz

Kur'an-ı Kerimin mucizesi belagatındadır. Bu mucizenin ispatlanmasının yolu, onun dilsel özelliklerini ve anlatım yöntemlerini ortaya koymaktır. Bu bağlamda çalışmamız, İbrahim Suresi örneğinde, dilcilerin üzerinde ittifak ettikleri belagat kuralları ışığında, Kur'an'ı Kerim'in haberleri aktarmada kullandığı üslubu araştırmaya hedeflemektedir. Çalışmamız üç bölümden oluşmaktadır. Birinci bölümde, suredeki haberlerde bulunan farklı belagatların amaçları ele alınmıştır. Böylece haberin içeriği ve konumuna göre belağattaki amacının da değiştiği fark edildiği ortaya çıkmıştır. Sonra ikinci kısımda, ilahi beyanın, muhatapların durumunu dikkate alarak haberi vurgulamadaki açıklığı ele alınmıştır. Böylece surenin ele aldığı konulara uygun olduğu için surede geçen inkârî haber türünden olduğu ortaya çımıştır. Üçüncü bölümde ise haberin te'kidinde Kur'an'ı Kerim'in genel kuralların dışına çıkmasının belagat açısından nedenleri incelenmiştir.

Anahtar Kelimeler: Kur'an-1 Kerim, Belagat, Üslup, Haber, İbrahim Suresi

\section{The Rhetoric of al-Khabar in Surat al-Ibrahim}

\section{Abstract}

The miracle of the Qur'an is in it rhetoric (Balagha). The way to prove this is to reveal its linguistic properties and methods of expression. This research aimed to study the style that Holy Qur'an used to convey the (AlKhabar) in the light of the rhetorical principles which are taken by the scholars. therefore, Surat Ibrahim was chosen to be researched. The research consists of three parts. in the first part stated that Holy Quran took out the (Al-Khabar) to many rhetorical meanings and noted the rhetorical purpose were varied according to the content of the (Al-Khabar) and the goal for which it was given. Thus, it became clear that the purpose of the (Al-Khabar) was changed according to the content and position of the (Al-Khabar) in the second part, the researcher proved the precision of Holy Quran statements with regards to assuring (Al-Khabar) to be Commensurate with the state of the recipients. It was also observed that most of the (Al-Khabar) in the Surah was (Inkaree) type, this is due to the theology issue in the Surah, where Allah's messengers and faithless people were arguing about the truth. The third part presented the rhetorical purposes which made Holy Quran violate the general rule in terms of assuring the (Al-Khabar).

Keywords: The Holy Quran, Rhetoric, Wording, al-Khabar, Surat al-Ibrahim. 
الحمد لله الذي اختار لأحكامه ومعانيه غرة كلام العرب وفخر تراكيبهم وعالي أساليبهم، وجعل معجزته في

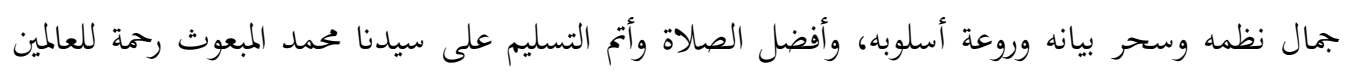

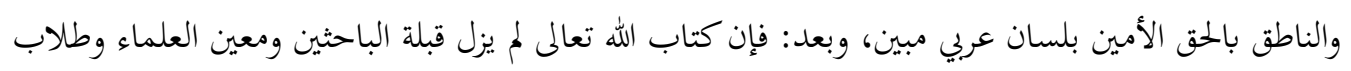

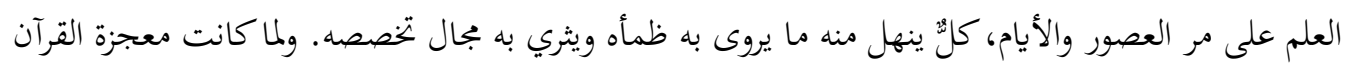

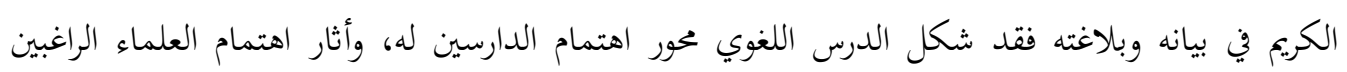

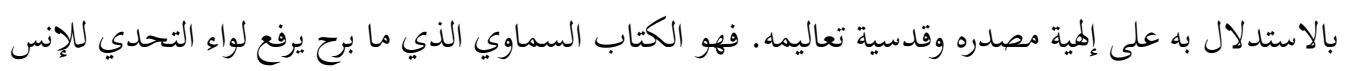

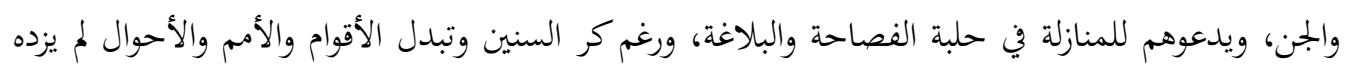
قدمه إلا جدة وأصالة.

وإذا كانت جوانب إعجازه اللغوي وبلاغة نظمه وبيانه جلية عند الرعيل الأول من العرب المعاصرين لنزوله

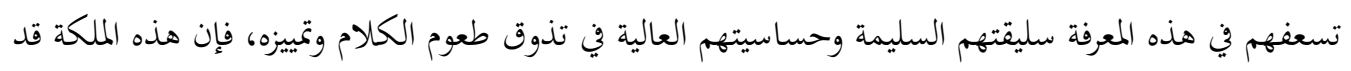

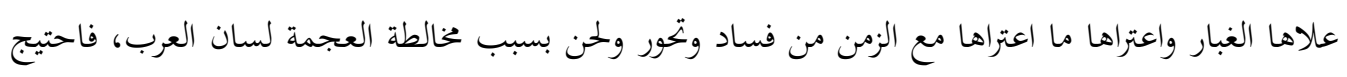

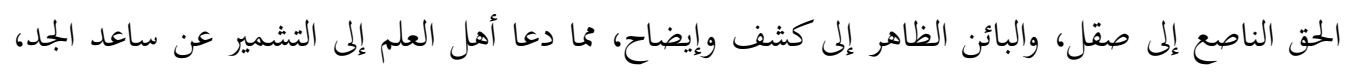

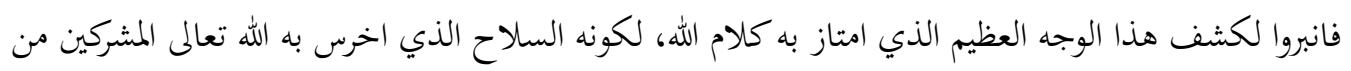
العرب وأقام به عليهم الحجة، فوجب أن يظل بارزاً تتناقله الأجيال برهاناً صادقاً على نسبة هذا لهذا البيان للعليم

والحديث عن بلاغة القرآن الكريم يعني الاحتكام إلى فنون البلاغة الثلاثة المعاني والبيان والبديع بغية الاستدلال

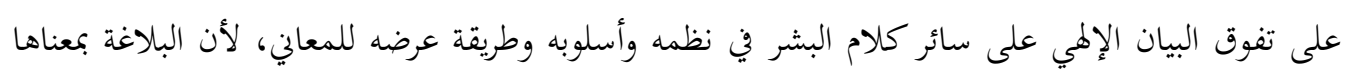

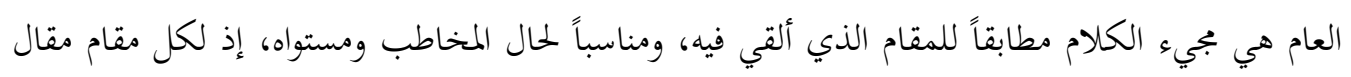

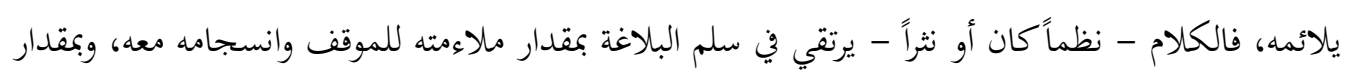

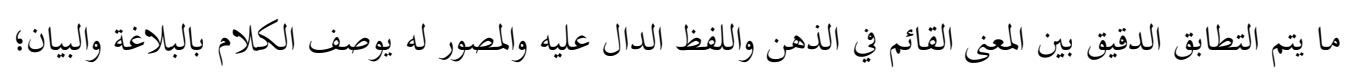

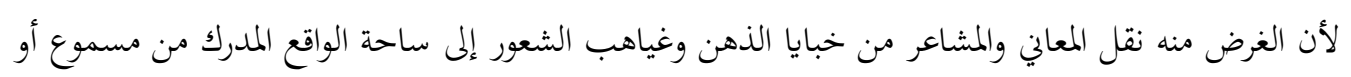

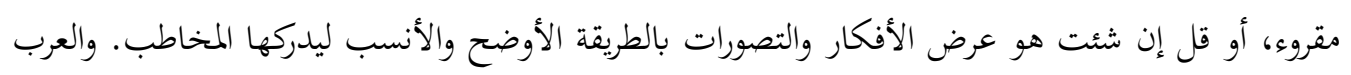

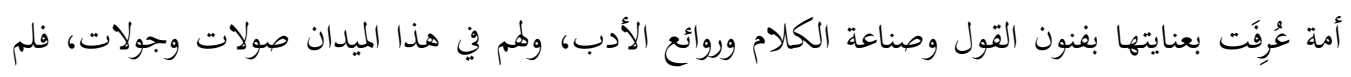

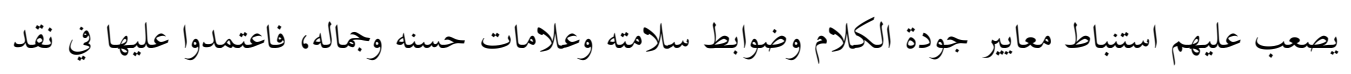
الشعر والنثر وساروا على ضوئها في دراسة النظم القرآني، فكان لعلماء البلاغة جهود مباركة في تحلية المراد

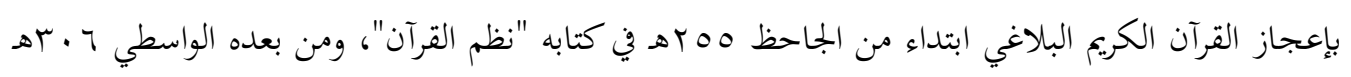




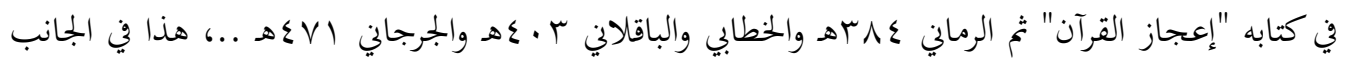

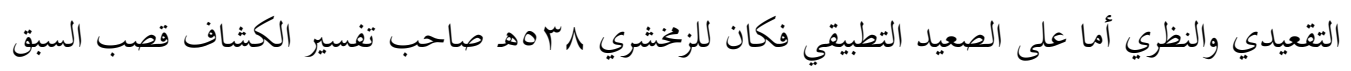

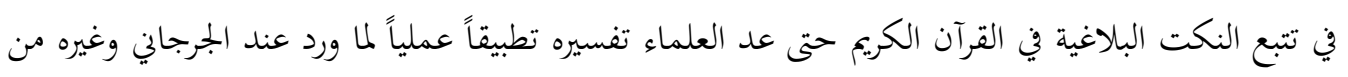

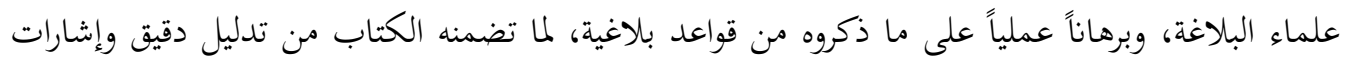
لطيفة ، أبرزت مواطن الجمال البلاغي وروعة البيان التي اختص بها كتاب الله.

وقد شكل هذا الكتاب مع غيره من التفاسير التي اعتنت بالجانب البلاغي من القرآن الكريم حقلاً خصباً

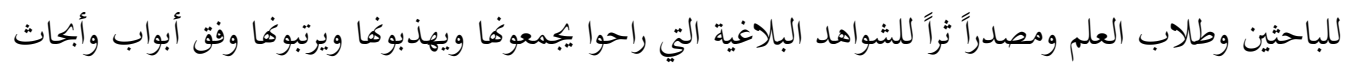

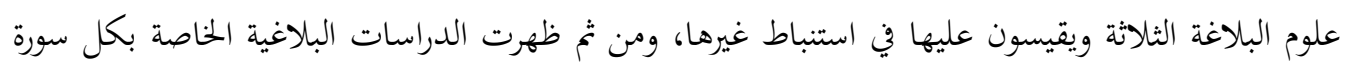
من سور القرآن الكريع، وكان للجامعات دور مهم في تشجيع طلبة الدراسات العليا على دخول هذا المضمار

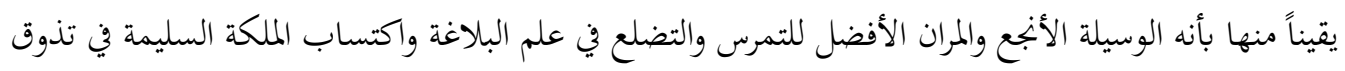
عال الكلام والنسج على منواله.

وقد دفعني ذلك إلى المساهمة بشيء في هذا الاتحاه فعقدت العزم - مستعيناً بالله - على خدمة كتابه العزيز

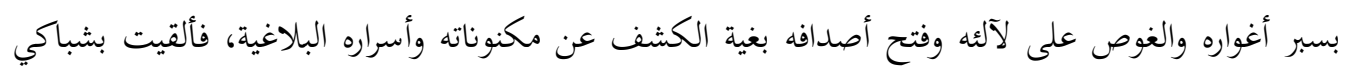

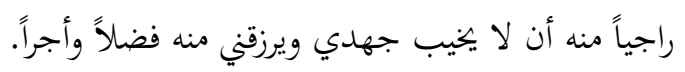

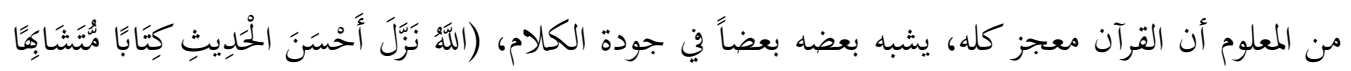

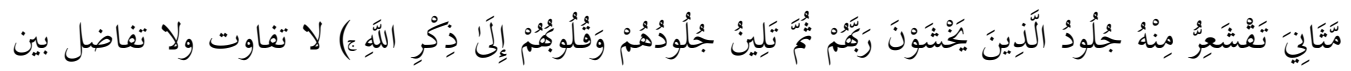
سوره في فصاحة المفردات وبلاغة النظم، ومن هنا وقع اختياري على سورة إبراهيم حقلاً للدراسة، ولما كان لمان

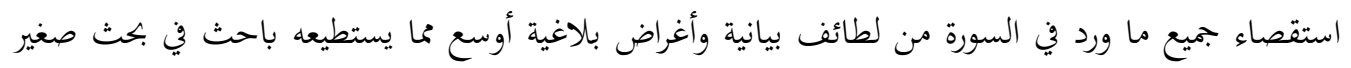

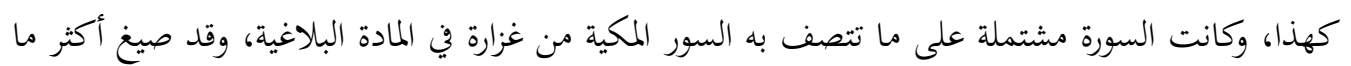
ورد فيها من المعاني بأسلوب الخبر، رأيت من المناسب تتبع الشواهد البلاغية للأسلوب الخببري بتناول أغراضه وأضرابه ودواعي خروجه على الظاهر، وما انطوى عليه من الدقة في التعبير والإحكام في الصنعة اللغوية. فالسورة

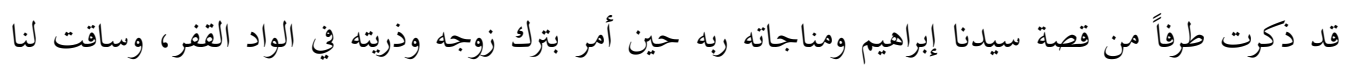

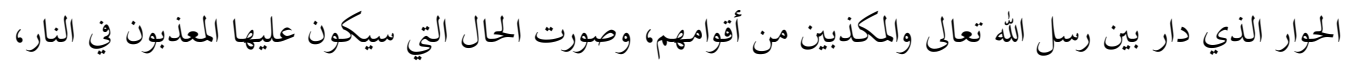

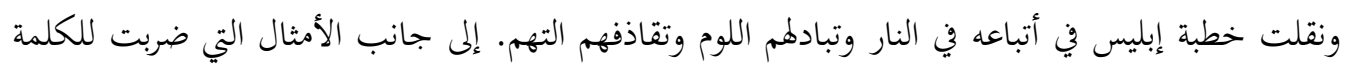
الطيبة والحبيثة، وكل ذلك بأسلوب خبري رصين متنوع الأغراض ومتعدد الأضراب.

أهمية البحث

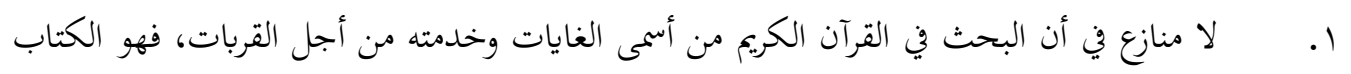

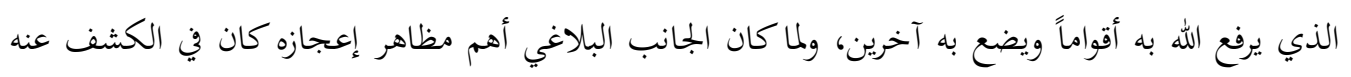

Türkiye İlahiyat Araştırmaları Dergisi

Turkey Journal of Theological Studies

[Tiad: 2602-3067]
Cilt / Vol: 2,

Say1/Issue: 1 ,

2018 
ترسيخ لإيماننا بسماويته وبرهان ساطع وسيف مشهر في وجه المنكرين والجاحدين له، وكان الاشتغال بمثل هذه البحوث سعياً طيباً وعملاً مباركاً في سبيل حفظ مصدر الإسلام الأول ودستوره الخالد.

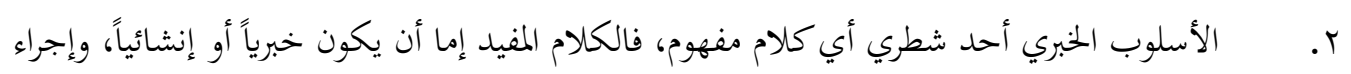

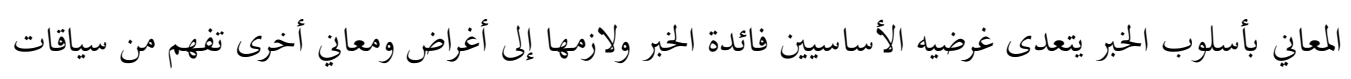

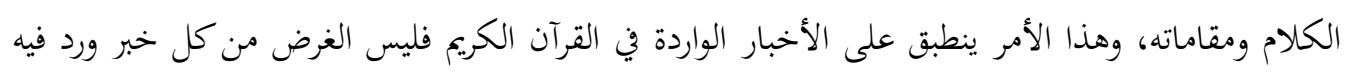

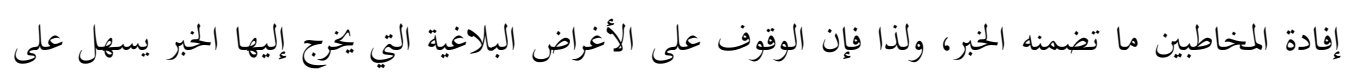

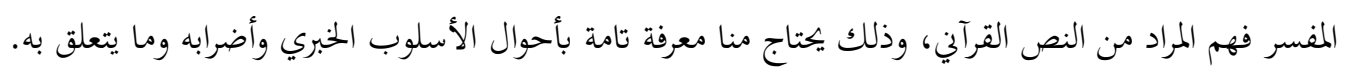

هدف البحث

الغاية من هذا البحث التدليل على أن القرآن الكريم يتربع في ذروة البلاغة العربية رغم سيره على سنن كلام

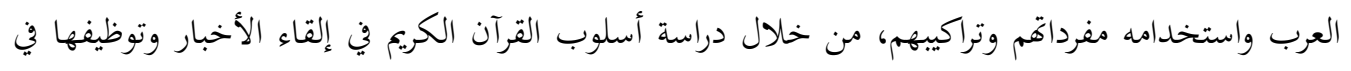

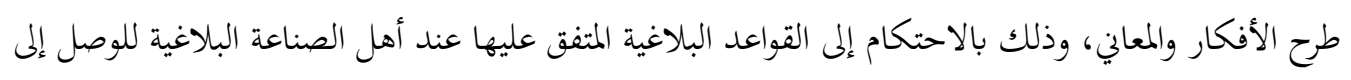

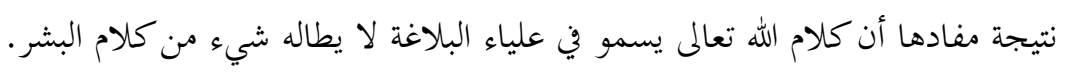

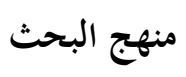

بما أن البحث دراسة في البلاغة فإنني ألتزم القواعد التي اعتمدها أهل البيان في تقييم الكلام، وأقدم للقاعدة

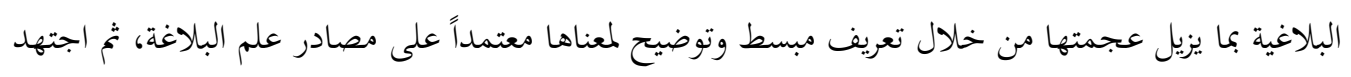

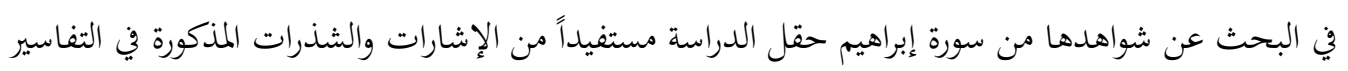
إضافة إلى ما هداني إليه نظري و تأملي وملكتي البلاغية. تمهيد: بين يدي سورة إبراهيم

سورة إبراهيم هي السورة الرابعة عشرة حسب ترتيب المصحف الشريف، تقع بعد سورة الرعد وتسبق سورة

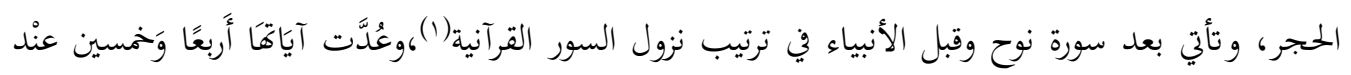

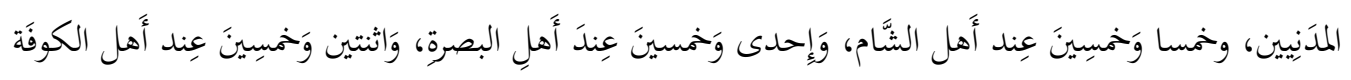
وهذا الأخير هو ما نجده في مصاحفنا.

(1) ينظر : الرازي، عبد الله محمد بن عمر بن الحسن بن الحسين، مفاتيح الغيب للرازي، دار إحياء التراث العربي - بيروت، الطبعة الثالثة - . بعا هـ، 
وروى القرطبي عن الحسن وعكرمة وجابر قولم إها مكية(r) كلها وهو مذهب الجمهور(r)، فيما روي عن ابن

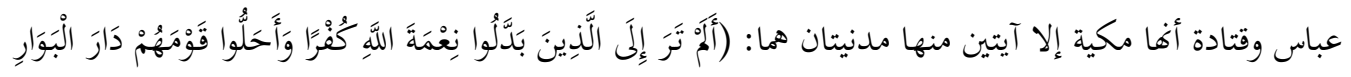

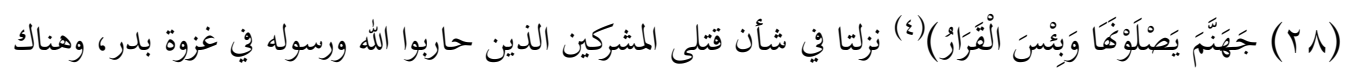

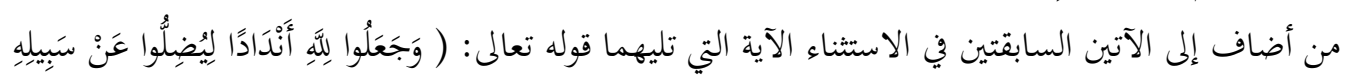

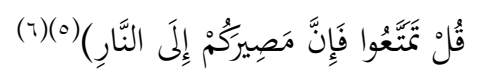

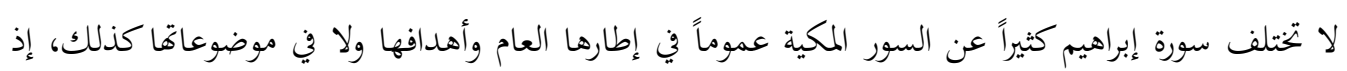

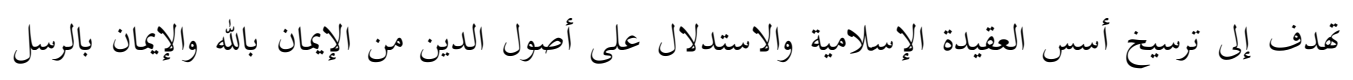
والأنبياء والإيمان بالبعث والنشور والحساب والجزاء.

وتبين أن من فضل الله تعالى على البشر أن شملهم كلهم بنعمه لم يفرق بين مؤمن به وكافر، ولكن تؤكد في الوقت نفسه على أن خاتمة الشاكر للنعم تختلف عن مآل الجاحد وأن الناكرين لنعم الله والظالمين سينالهم في الآخرة عقاب من الله عظيم.

وتحقيقاً لهذا الغرض وإنجازاً لهذا الهدف جُعِل محور السورة الأساس الرسالة والرسل؛ وحدها ووظيفتَهم ووحدة

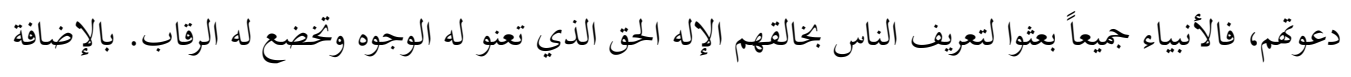

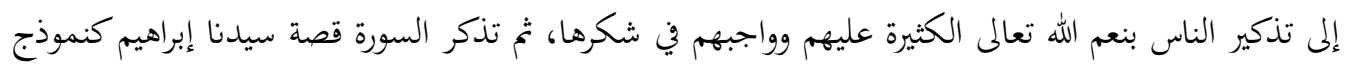

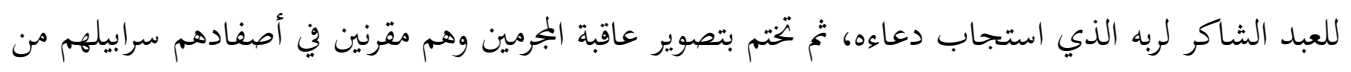
قطران تغشى وجوهم النار. أعاذنا الله من تلك العاقبة ورزقنا رضوانه. ولكن إذا أمعنا النظر في جزئيات السورة وأمتعنا الفكر في سير آياتما ظهرت لنا حقيقتان تظلان جو السورة

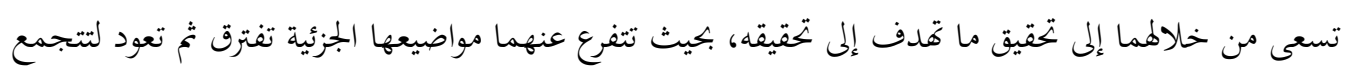
وتنضوي تحت هاتين الحقيقتين: (v)

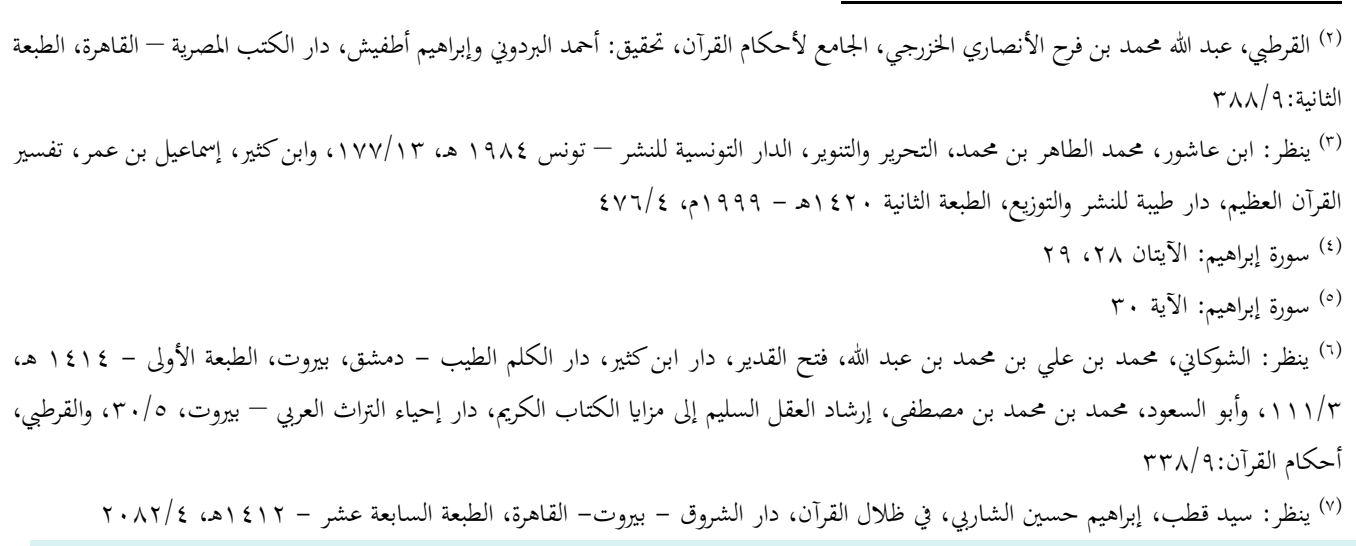


İbrahim Suresinde Haber Üslubunun Belagati/ The Rhetoric of al-Khabar in Surat al-Ibrahim

الحقيقة الأولى: حقيقة الرسالة والرسول ووحدة الرسالة والرسل ووحدة دعوقم ووقوفهم أمة واحدة في مواجهة الجاهلية المكذبة بدين الله تعالى على اختلاف الأزمنة والأمكنة.

الحقيقة الثانية: وتتحدث عن نعم الله تعالى على البشر، وزيادتما بالشكر وتتناول الذين كفروا بهذه النعمة

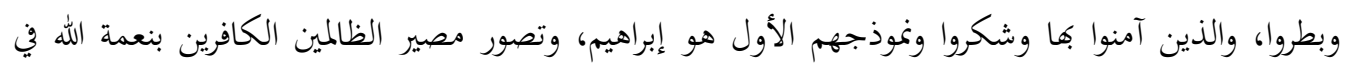
سلسلة من أعنف مشاهد القيامة، وأحفلها بالحركة والحياة..

\section{المراد بالخبر في مصطلح البلاغيين}

استقر رأي علماء البلاغة على تقسيم الكلام إلى خبر وإنشاء. ودليلهم على ذلك الخصار الكلام المفيد فيهما،

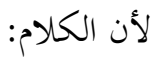

إما أن يقال فيه: إنه مطابق للواقع أو غير مطابق للواقع وهذا الصنف من الكلام هو الخبر، أو أنه لا يحتمل أن

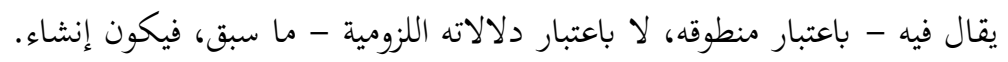

$$
\text { فالجملة المفيدة تنقسم إذاً على قسمين: }
$$

القسم الأول: الجملة الخبرية، وهي التي تتضمن الإخبار عن شيء إما سلباً أو إيجاباً، بقصد "الإعلام بأن الحكم

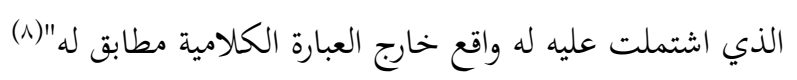

القسم الثاني: الجملة الإنشائية، وهي التي ليس لمدلولها خارج يحتمل أن يطابقه أو يخالفه وإنما ينشأ مدلولها مع كأل

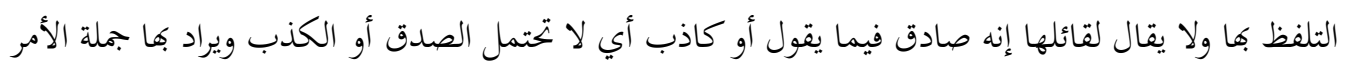

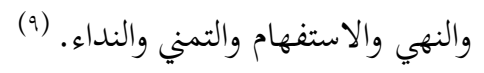

وعليه فالحبر هو ما احتمل الصدق أو الكذب لذاته باعتبار كونه بجرد كلام(·)، دون نظر إلى قائله(11)، نحو قولنا: الجو بارد، الطريق طويلة..

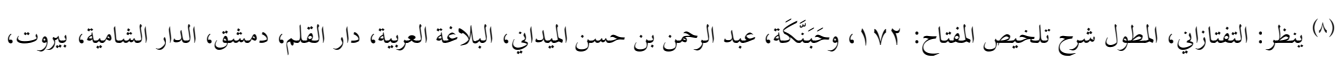

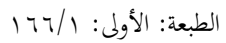

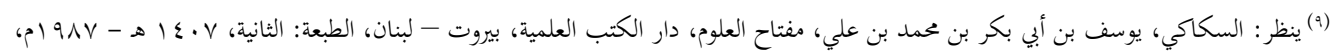

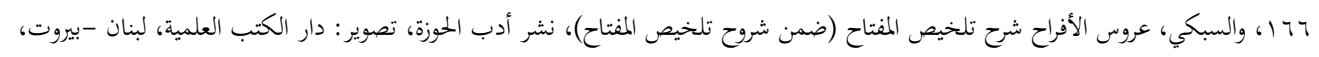
$1 \cdot \varepsilon / 1$ (.) ينظر : المغربي، ابن يعقوب، مواهب الفتاح في شرح تلخيص المفتاح، (ضمن شروح تلخيص المفتاح)، نشر أدب الحوزة، تصوير: دار الكتب العلمية، لبنان - بيروت، 170 (1) إيراد هذا القيد في التعريف لتدخل في التعريف الأخبار الواجبة الصدق كالأخبار الواردة في القرآن الكريم والسنة النبوية، وأخبار الرسل، والبديهيات

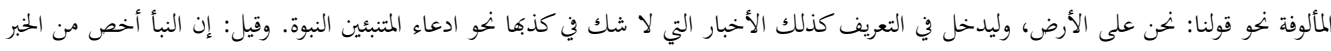

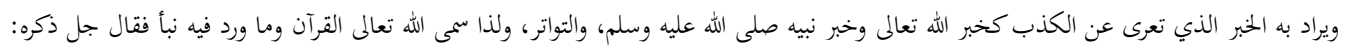




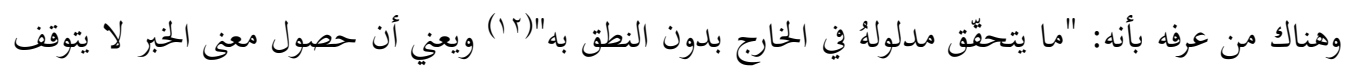

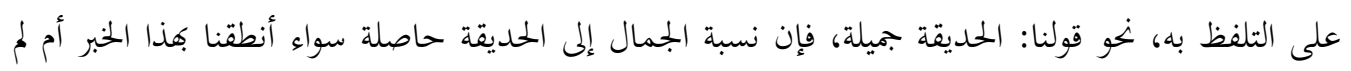
ننطق (r) أ، بخلاف الإنشاء الذي يتولد مع التلفظ ويكون عدماً قبله.

وبمهور أهل العلم(ء) على أن مناط الحكم على الخبر هو مطابقته للواقع الخارجي أو عدم المطابقة، فيكون صادقاً إن وافق الواقع وكاذباً إن خالفه. المبحث الأول: الغرض من إلقاء الحبر

جعل أهل البلاغة الأصل في إلقاء الخبر أن يكون لأحد غرضين(10):

الأول: إفادة السامع الحكم الذي اشتملت عليه الجملة، ويكون عند جهل المخاطب له، ويسميه أهل البلاغة فائدة الخبر.

الغرض الثاني: إعلام المخاطب أن المتكلم على علم بالحكم الذي تتضمنه الجملة، ويكون المخاطب في هذه

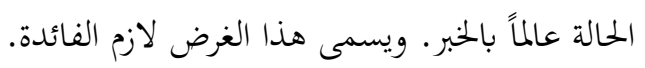

ولكن الملاحظ من كلام العرب أن المخبر يتحلل من هذين الغرضين في كثير من الأحيان ويخرج عليهما، فيسوق

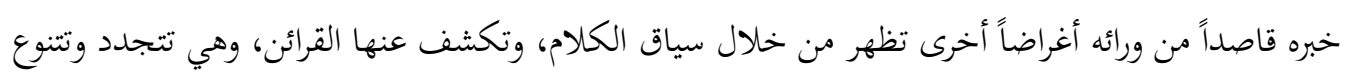

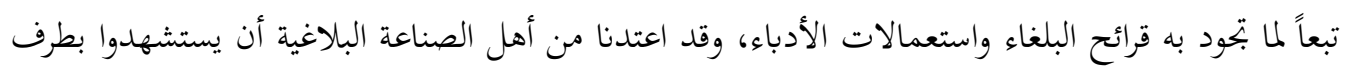
منها على سبيل المثال عن الحديث عن الخبر (17).

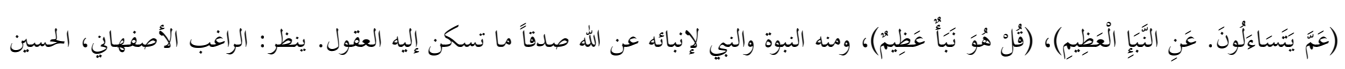

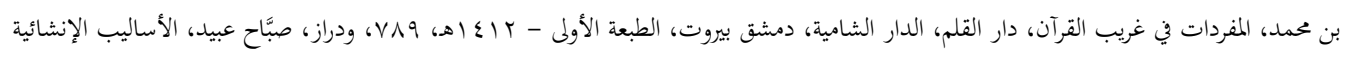

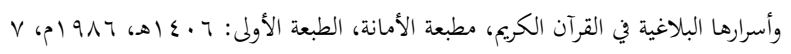

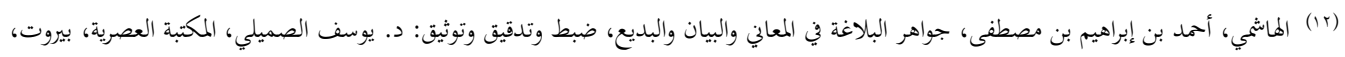

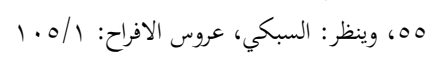
أ)

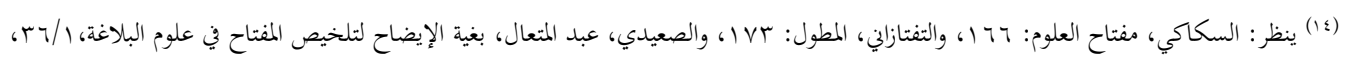

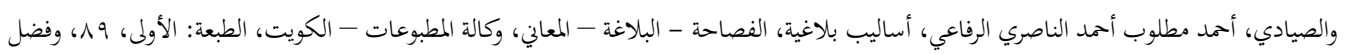

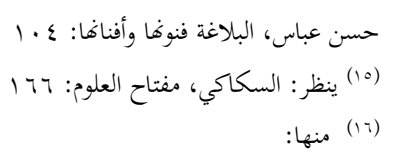

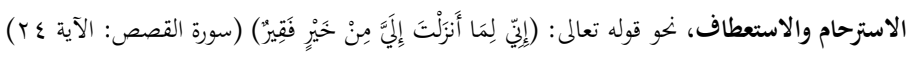

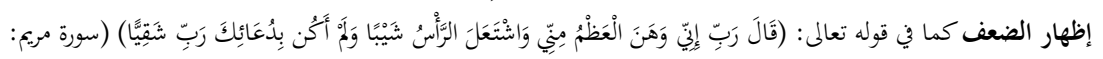
الآية ع ) جاء الخبر هنا معبراً عن ضعف العبد في حضرة خالقه.

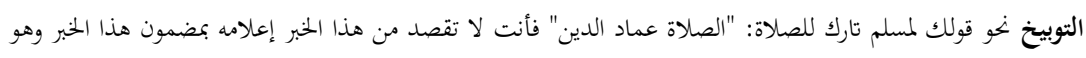

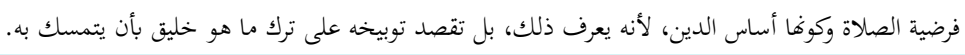


وإذا تتبعنا ورود الحبر في سورة إبراهيم نقع على أمثلة كثيرة خرج الحخبر فيها عن إطار الفائدة ولازمها لأغراض بلاغية متنوعة يكشف عنها سياق الآيات، نذكر منها:

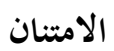

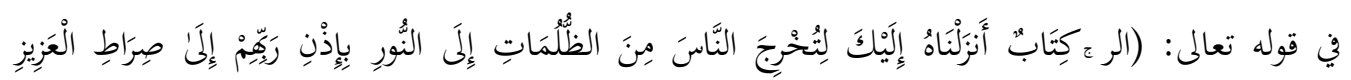

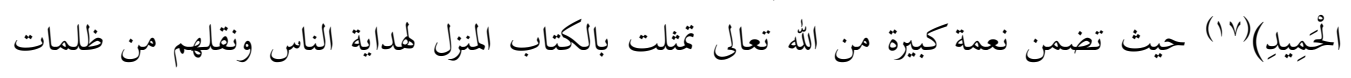
الضلال إلى نور الإيمان، على سبيل الامتنان.

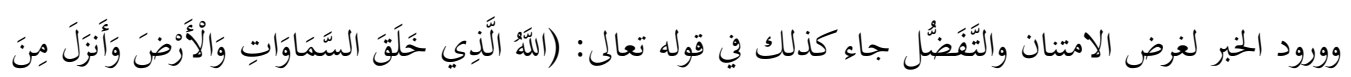

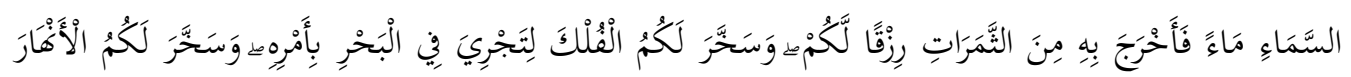

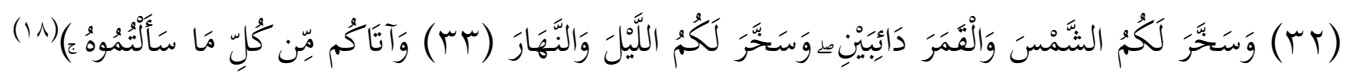

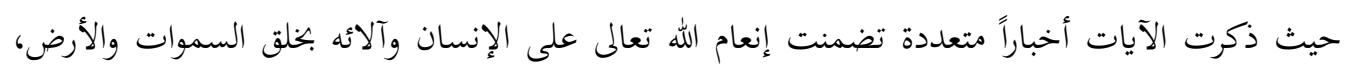

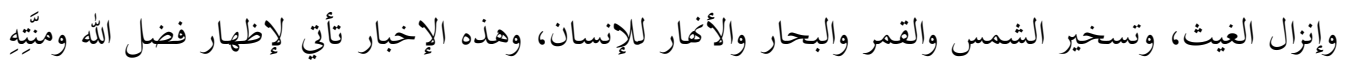

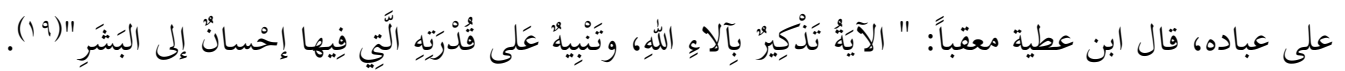

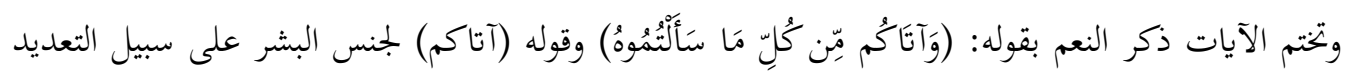

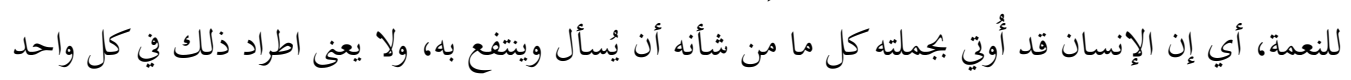
من الناس(r.). (r.)

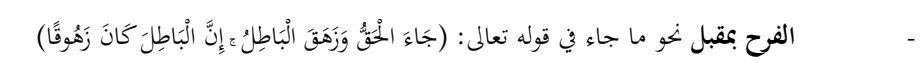

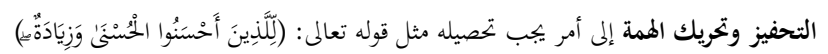

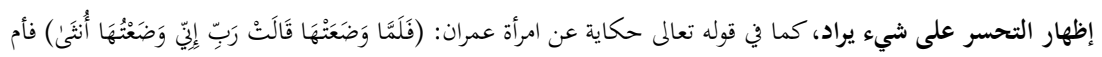

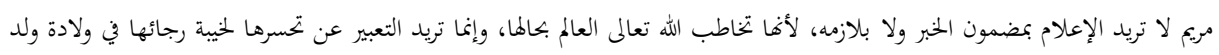

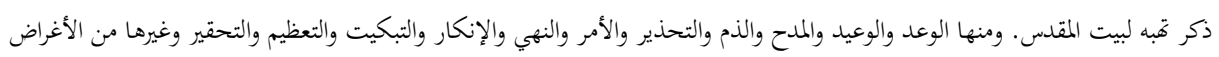

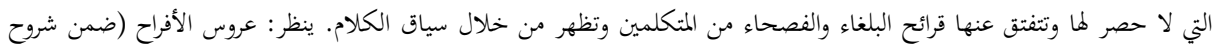

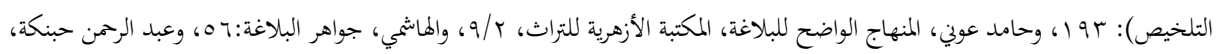

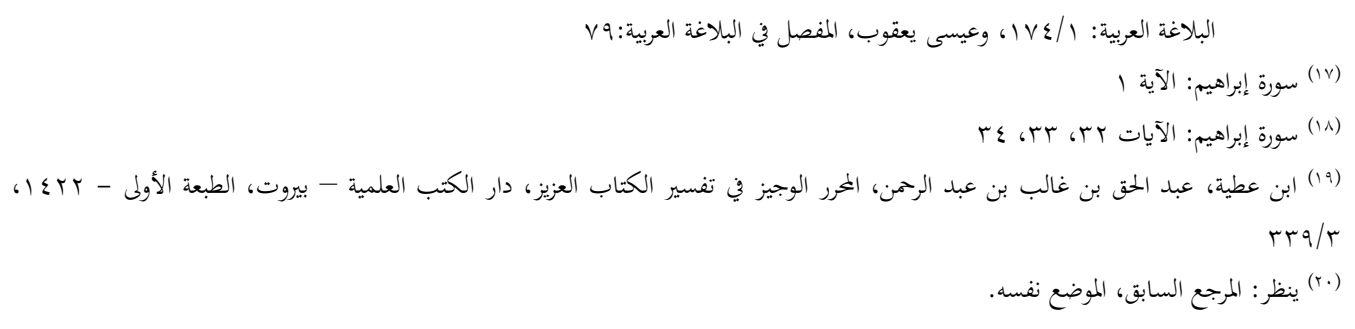


وفي قوله (كل ما سألتموه) قراءتان(r(الأولى المشهورة (مِّن كُلِّ مَا سَأَلْتُمُوه) فتكون (ما) إما مصدرية، ويكون

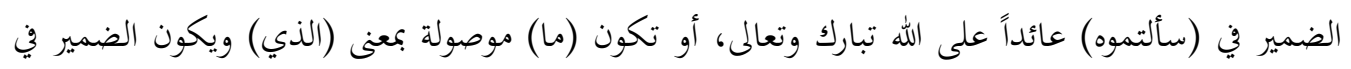

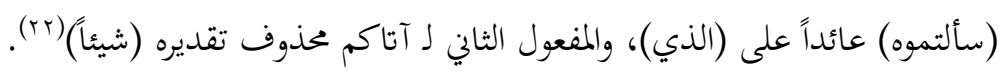

والقراءة الثانية للضحاك والحسن وقتادة ورويت عن نافع (من كُلِّ ما سألتموه) بتنوين (كلٍّ) فتكون (ما) مفعولاً ثانياً لـ (آتاكم)، وذهب بعضهم إلى اعتبار (ما) نافية على هذه القراءة، أي: أعطاكم من كلِّ شيئَاً ما سألتموه،

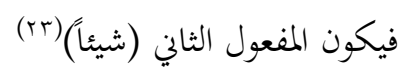
التنبيه والتحذير

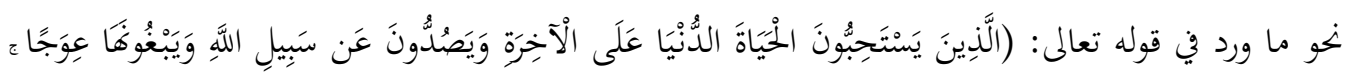

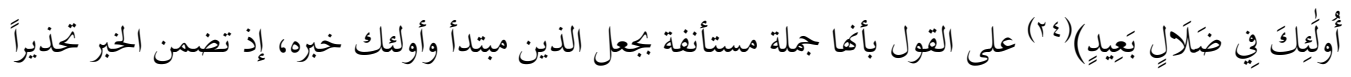

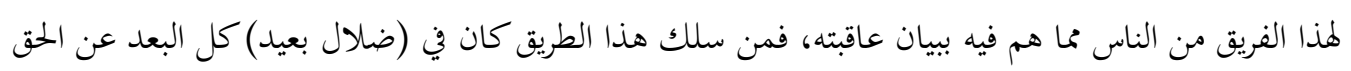
والخير.

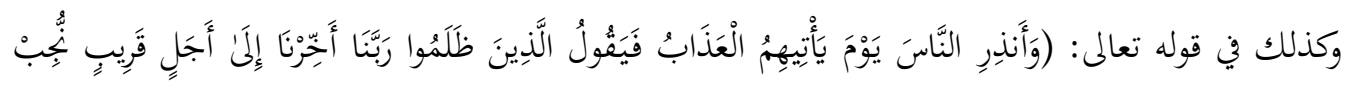

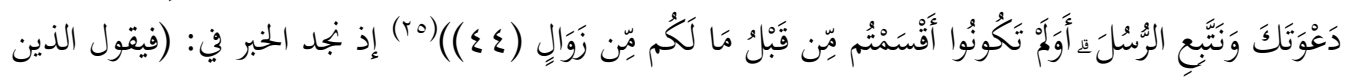

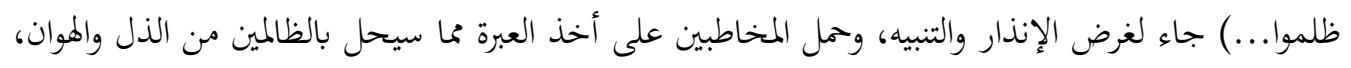

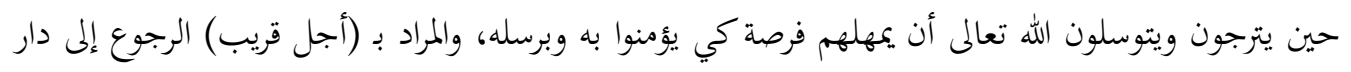

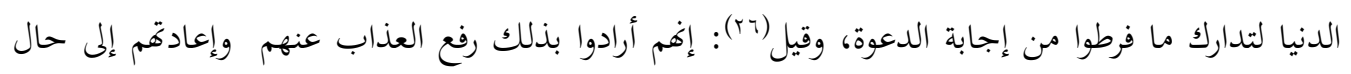

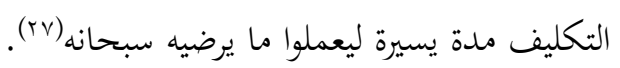

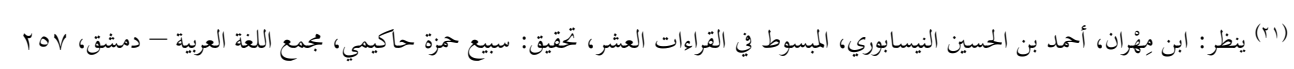

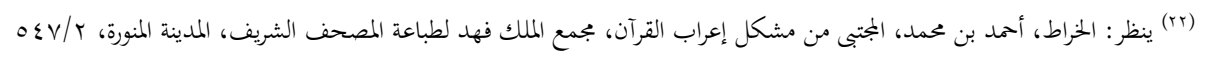

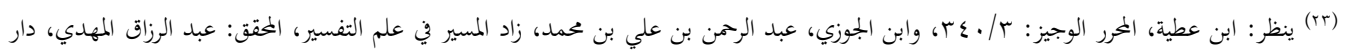

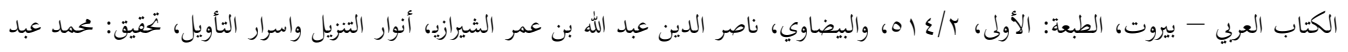

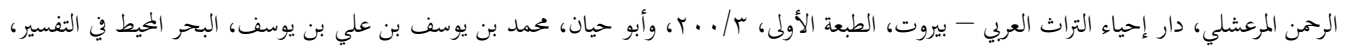

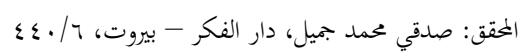

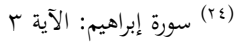
ع (ro)

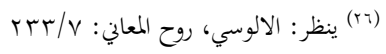

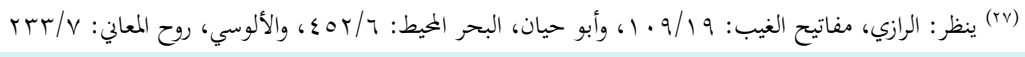




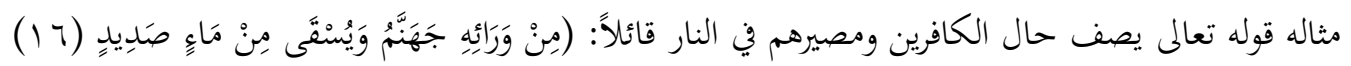

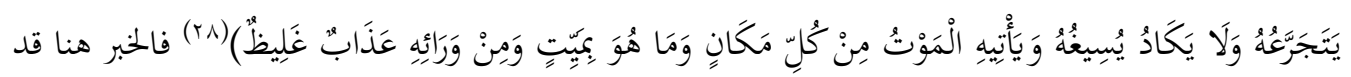

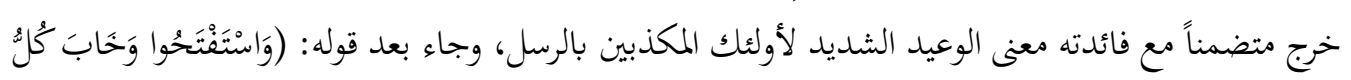
جَبَّارٍ عَنِيدٍ)(r9) الذي بين فضل فائله الله تعالى على رسله حين فتح عليهم، واستجاب دعاءهم في النصر وأظهرهم

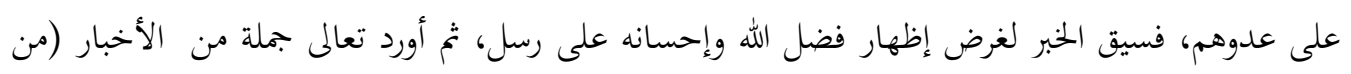

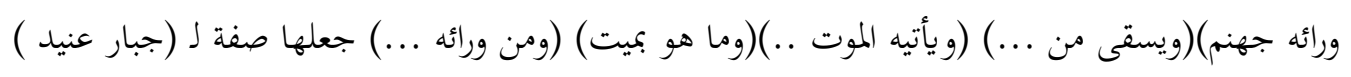

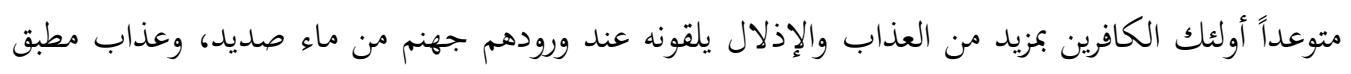

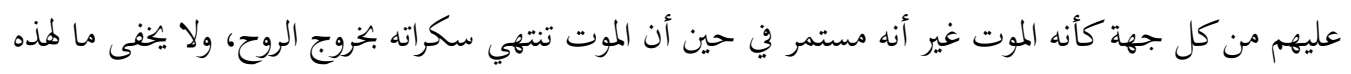
الأخبار من أثر في تخويف السامع وتفزيعه لما تحمله من التهديد والوعيد.

ولغرض الوعيد بزوال كل ما عمله الكافرون وأنتجوه جاء الخبر المتضمن تشبيه أعمال الكافرين يوم القيامة بالرماد

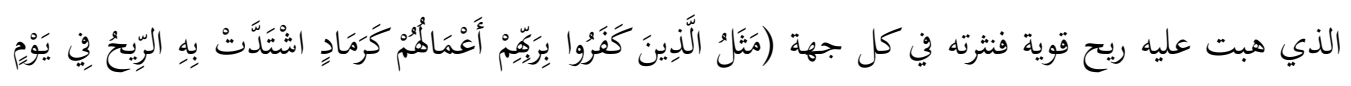

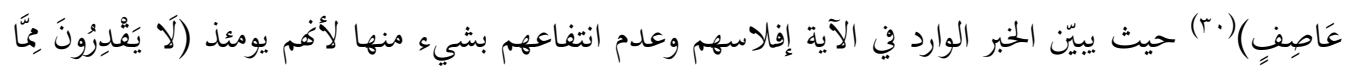

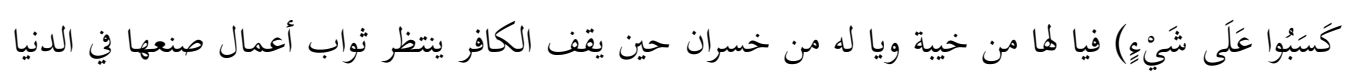

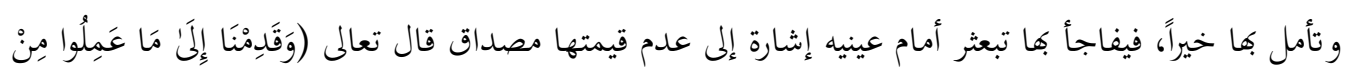

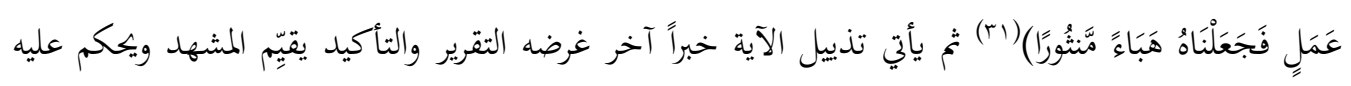
بقوله: (ذَلِكَ هُوَ الضَََّلَلُ الْبَعِيدُ).

التحفيز وتحريك الممة

نلحظ ورود الخبر في السورة لغرض بعث الهمم لنيل رضاء الله تعالى والفوز بثوابه من خلال الترغيب الذي نلمسه

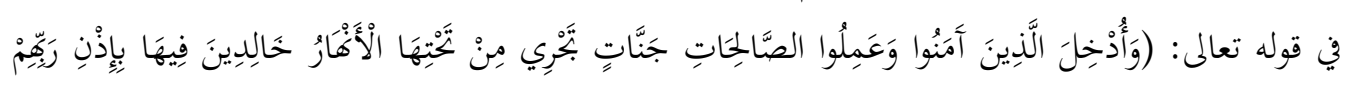

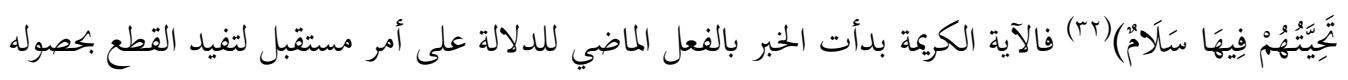

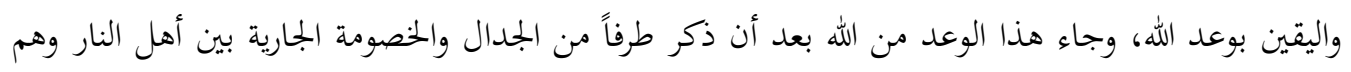
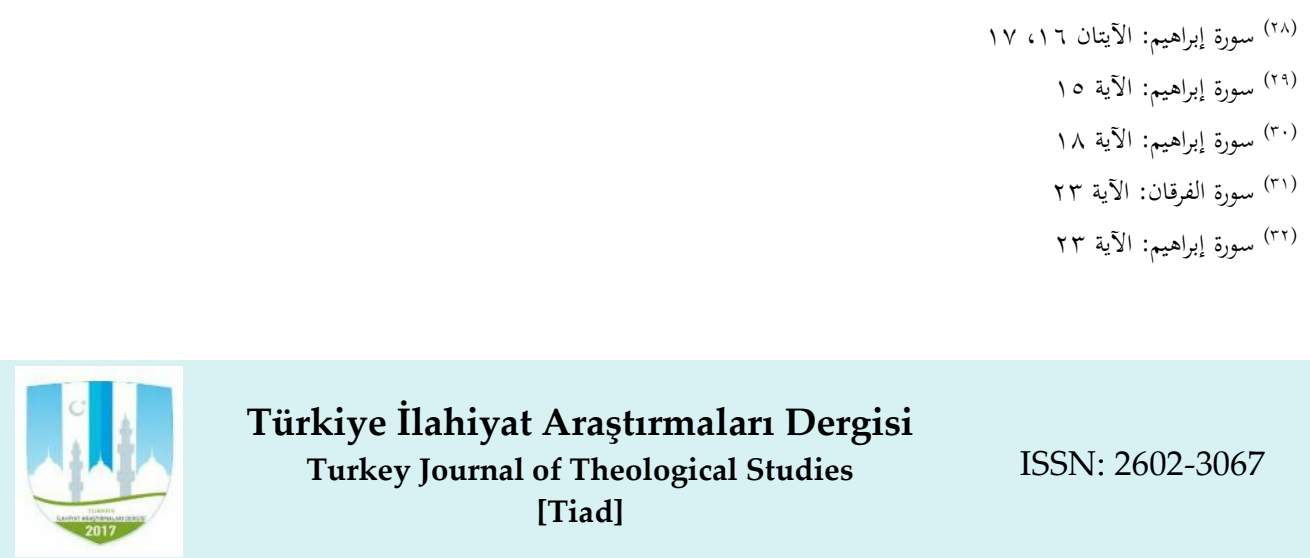
يتقاذفون التهم ويتبادلون اللّوم والتأنيب، فحسُن الانتقال بعد ذلك إلى وصف حال المؤمنين على سبيل الترغيب

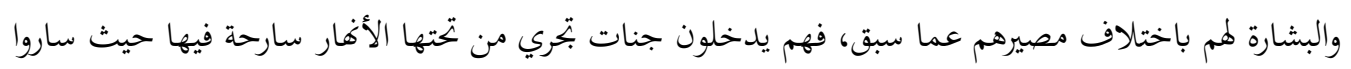

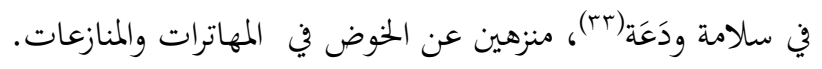

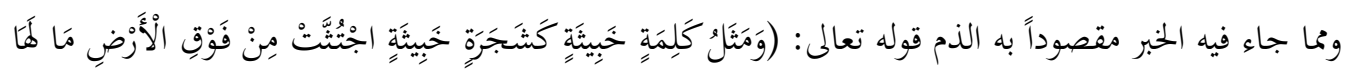

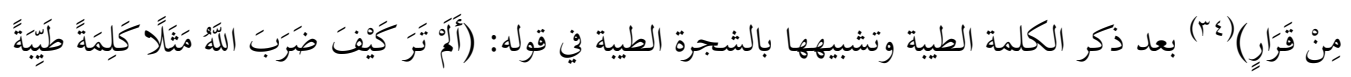

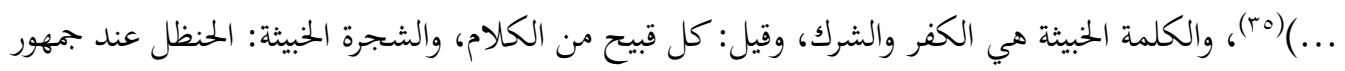

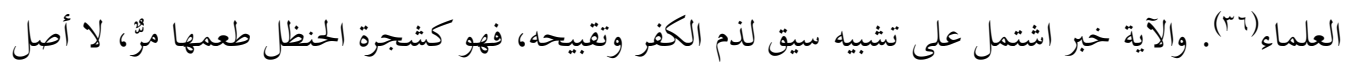

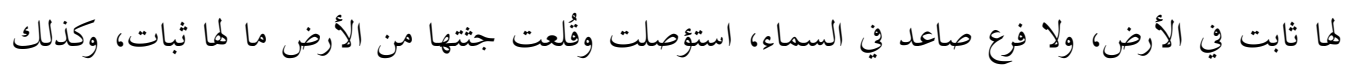

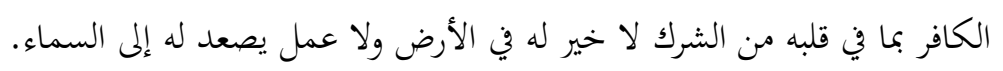

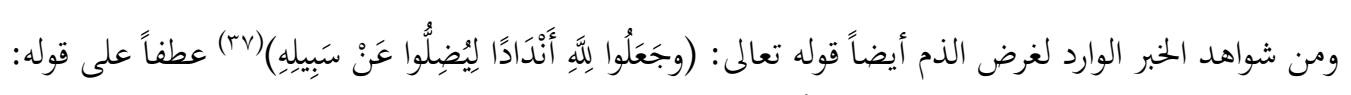

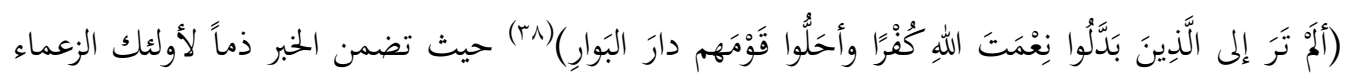

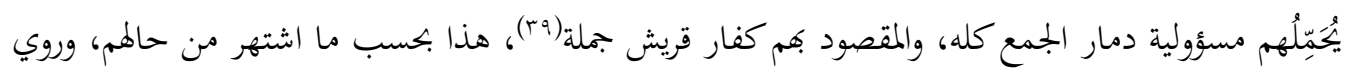

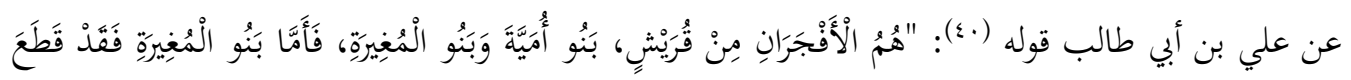

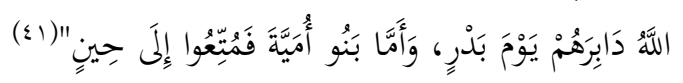

الاستعطاف وإظهار الضعف

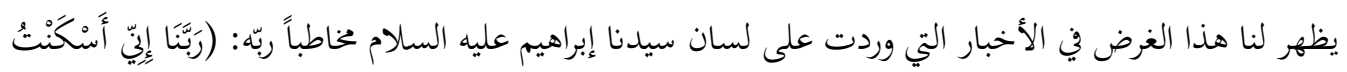

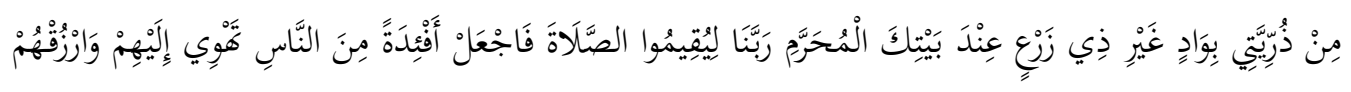

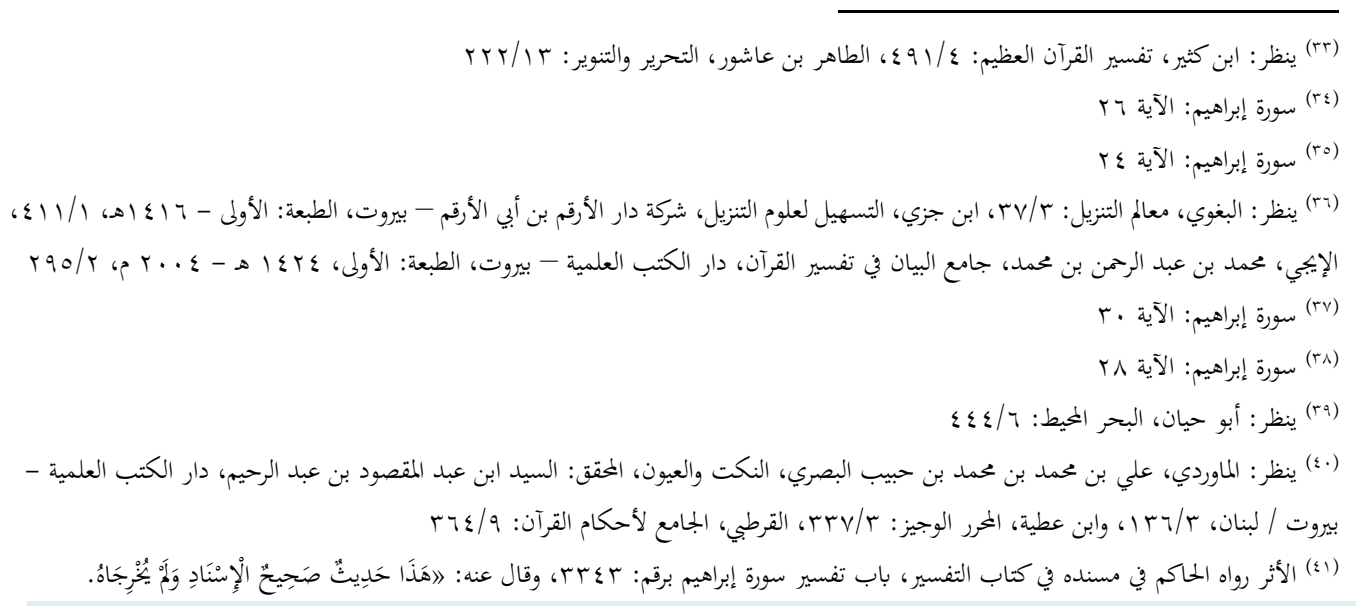




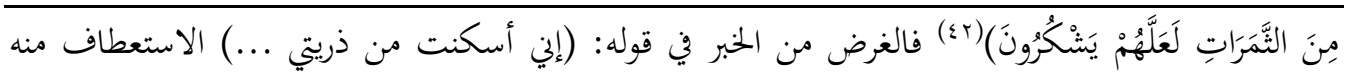

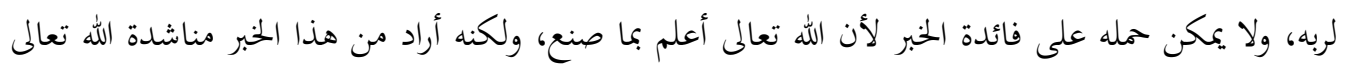

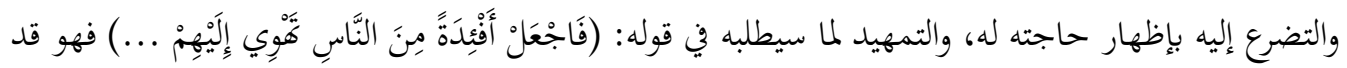

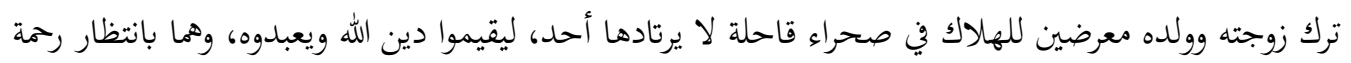
الله ولطفه. وكذلك جاء الحبر لغرض الاستعطاف وإظهار العجز إضافة إلى غرض الثناء والتعظيم في قوله تعالى حكاية عن

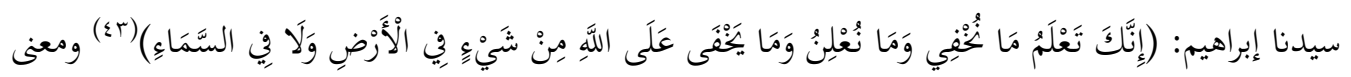

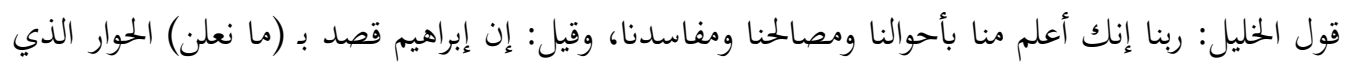

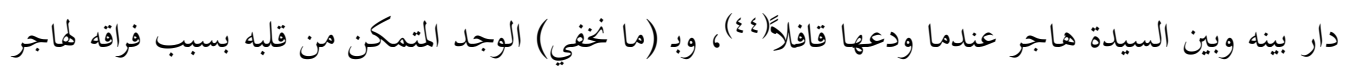

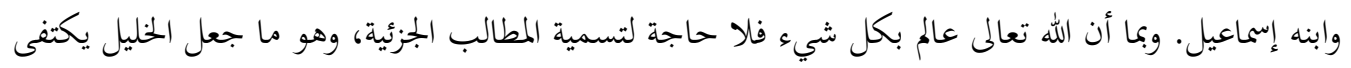
بتقديم شعائر العبودية بين يدي الله بإظهار ضعفه وعجزه، والاقتقار لرحمة الله تعالى، والحاجة لفضله ولطفه في تيسير أمره وتفريج كربته. ثم جاء الخبر الثاني الذي قصد منه إبراهيم عليه السلام الثناء على الله تعالى بأنه علّام الغيوب(\&) لا تخفى عليه خافية. الفرح وإظهار السرور

حينما انتهى إبراهيم عليه السلام من الثناء على الله تعالى انتقل إلى شكره على هباته، فجاء خبره بغرض إظهار

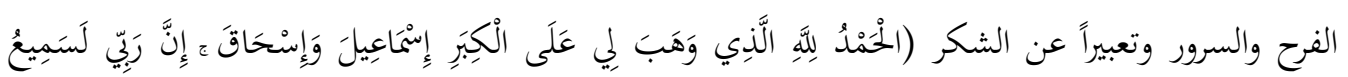

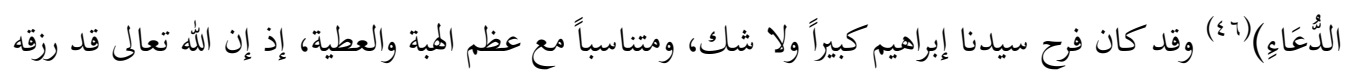
إسماعيل وإسحاق بعد طول انتظار وبعد انقطاع الرجاء بالإنجاب كما دلَّ عليه قوله: (على الكبر ).

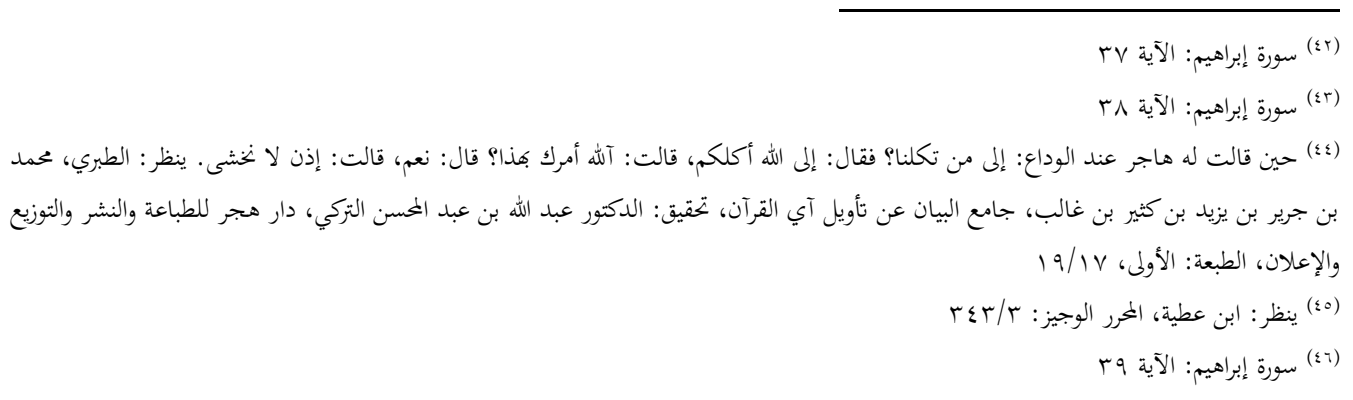




\section{العنيف والتوبيخ}

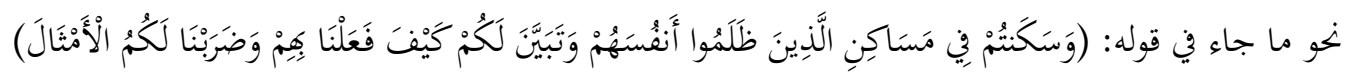

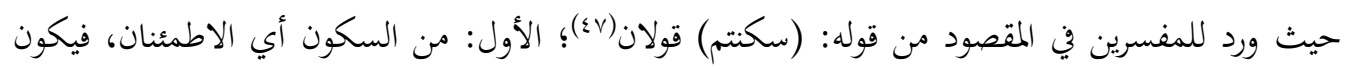

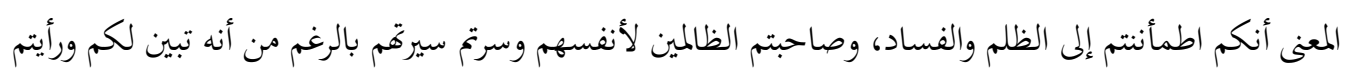

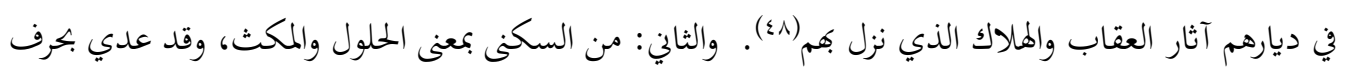

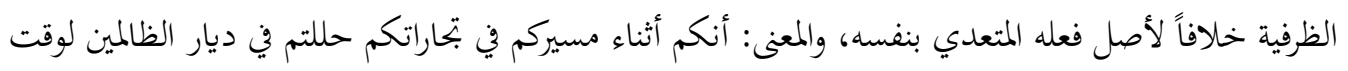
يكفي للاتعاظ وأخذ العبرة مما وقع بمم، في إشارة إلى واقع كفار قريش في رحلاقهم التجارية إذ كانوا يمرون بدياء

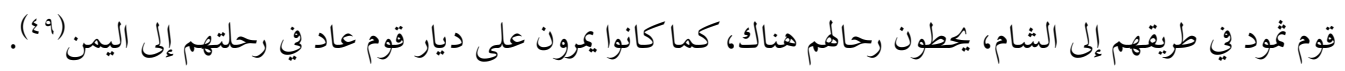

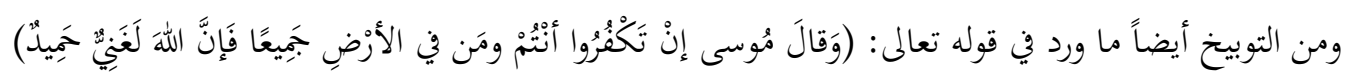

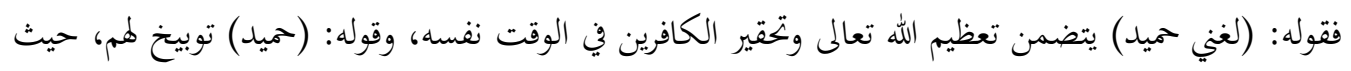

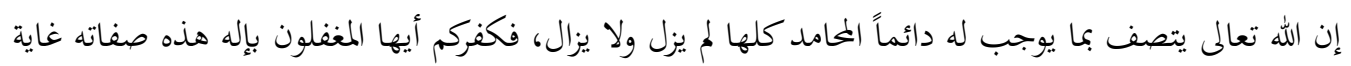

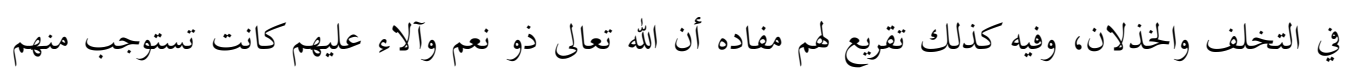

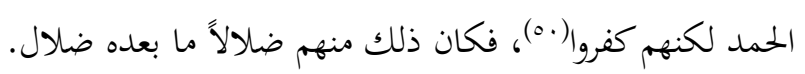

التحقير وإظهار العجز

ومن أغراض الخبر التي ظهرت في آيات سورة إبراهيم تحقير مكر الكفار، وإظهار عجزهم، في قوله تعالى: (وَقَّْْ

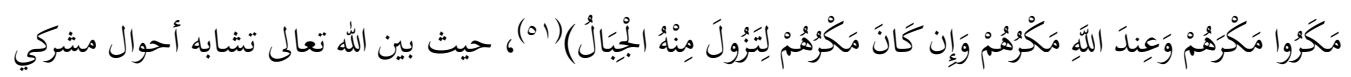

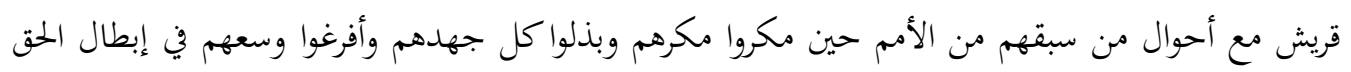

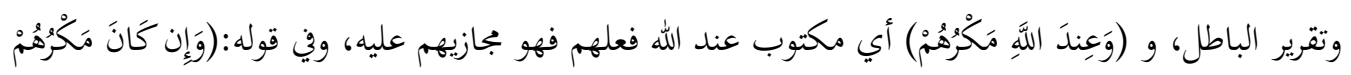

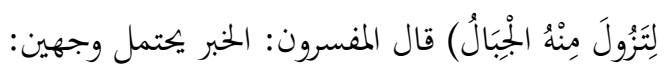

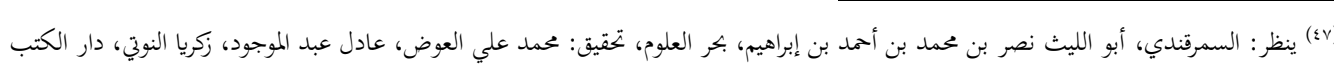

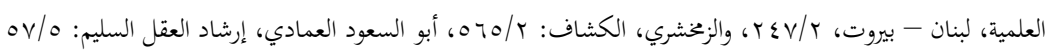

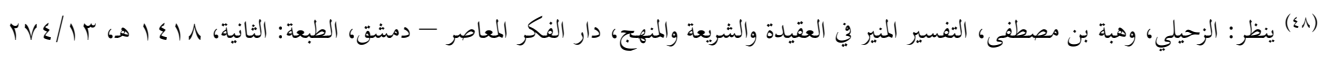

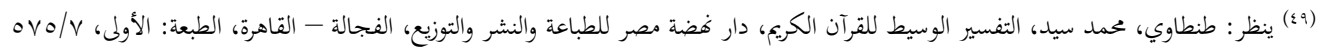

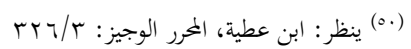

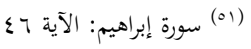


I İbrahim Suresinde Haber Üslubunun Belagati/ The Rhetoric of al-Khabar in Surat al-Ibrahim

الأول: تعظيم ملكرهم(r) وتبيتهم للشر وتدبيره حتى إنه من القوة والصلابة بحيث يؤثر في الجبال مضرب المثل

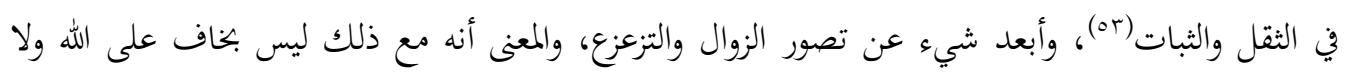
مجهول؛ بل هو في نطاق علم الله وطوق قدرة الله تعالى (وعند الله مكرهم).

والثاني وهو الأقرب: أنه تعالى أراد بالجبال آياته وشرائعه(\&) لأنها من الثبات والتمكن بمنزلة الجبال الراسيات،

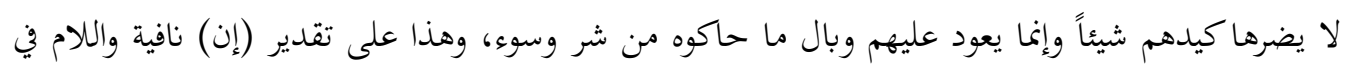

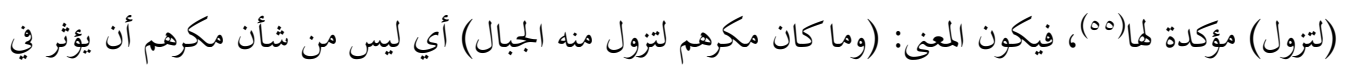
شرائع الله الراسخة رسوخ الجبال، وعليه يكون الغرض من إلقاء هذا الخبر التحقير من شأن مكرهم وتصغيره وتوينه، وفضحهم بإظهار عجزهم وفشل تدابيرهم. أغراض الخبر في خطبة إبليس في أتباعه

يلاحظ الباحث تنوع الأغراض من الأخبار التي وردت على لسان إبليس في جهنم حين وقف خطيباً في أتباعه،

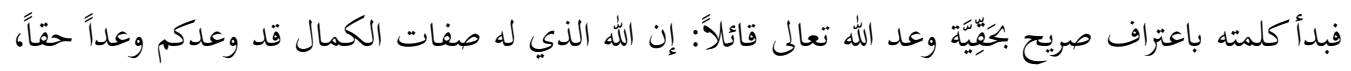

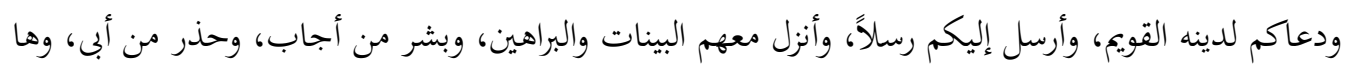

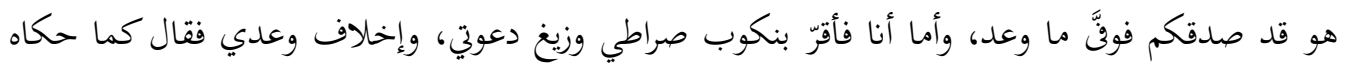

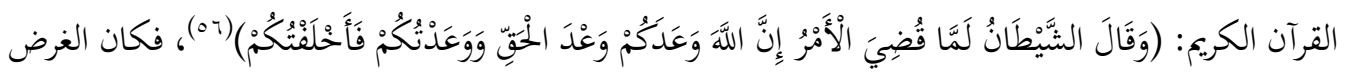

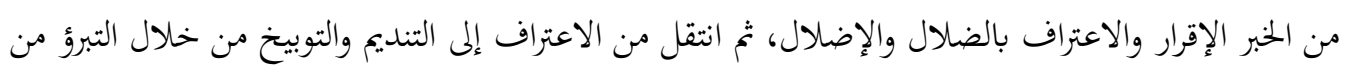

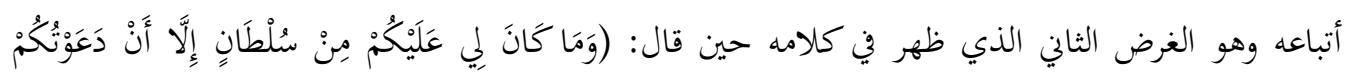

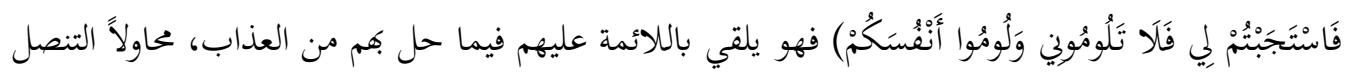

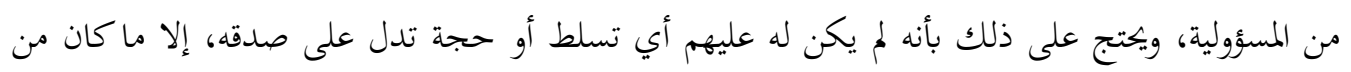

$$
\text { وسوسة وتزيين للمعصية وتسويل عليها. }
$$

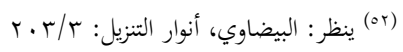

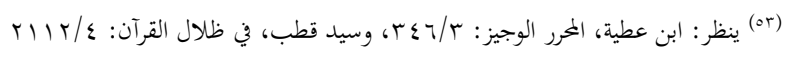

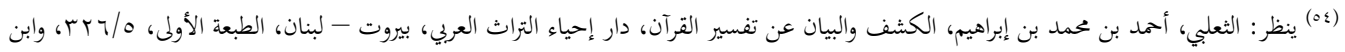

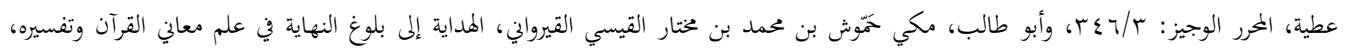

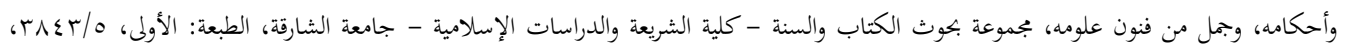

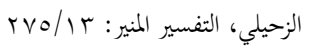

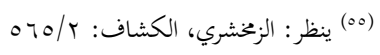
r r (07) 


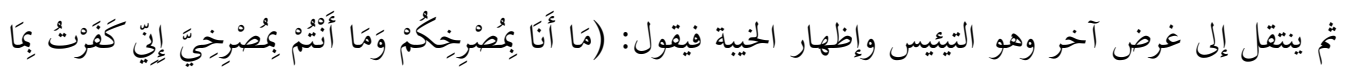

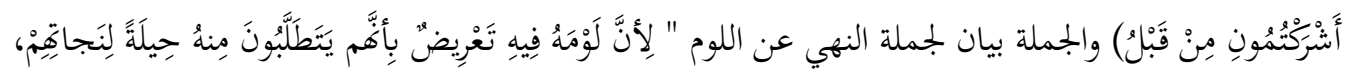

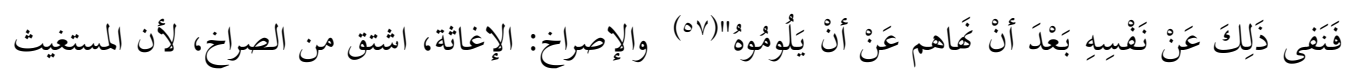

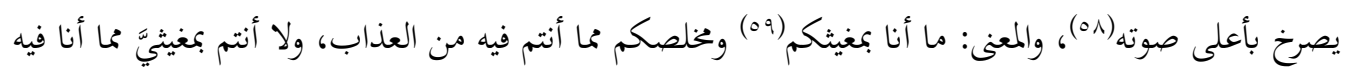

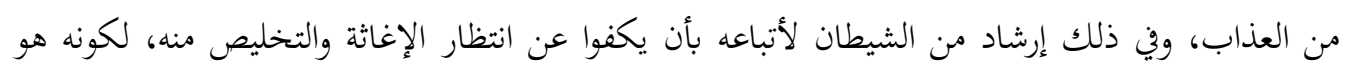

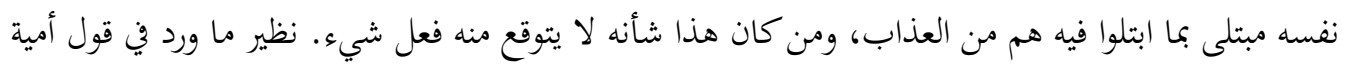
بن أبي الصلت (7.): (بن)

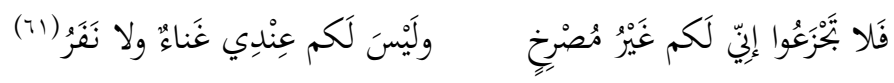

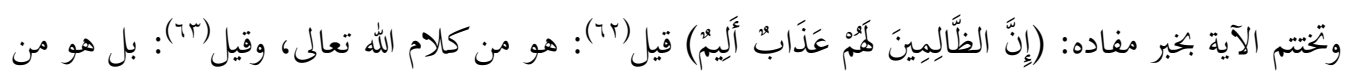

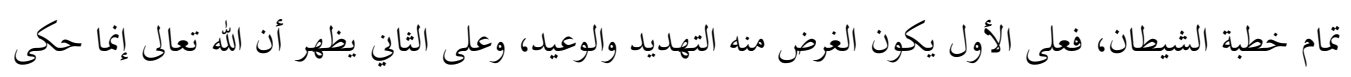
ما سيقوله إبليس في تلك اللحظة ليكون ذلك المشهد عبرة ولطفاً بالسامعين، وإيقاظاً لهم للنظر إلى عاقبتهم

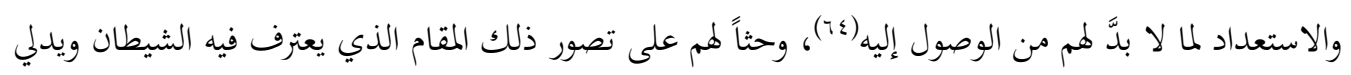
بشهادته، فيكون ذلك أدعى لهم للخوف والعمل على اتقاء ذلك الموقف وتخليص أنفسهم منه. وكان للرازي مذهب آخر فهو وإن رجح كون التذييل من كلام الله تعالى عاد ليقول: "ولا يَبْعُدُ أيْضًا أنْ يَكُونَ

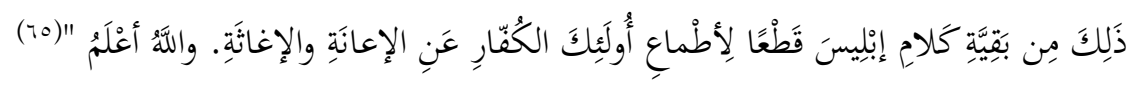

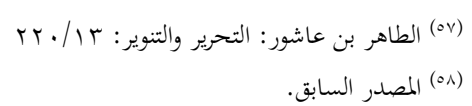

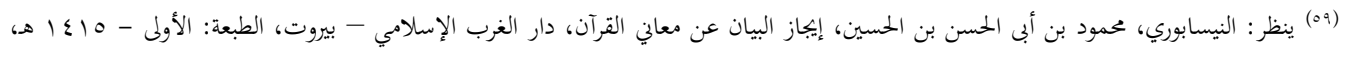

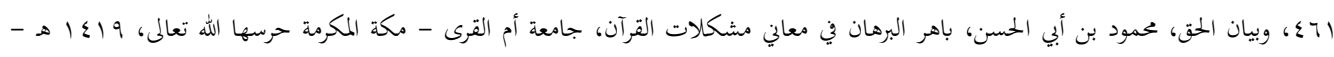
VTr/r (p) 991

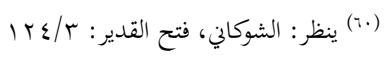
(1ا7) ذكره نشوان الحميري في " شمس العلوم ودواء كلام العرب من الكلوم " دار الفكر المعاصر (بيروت - لبنان)، دار الفكر (دمشق - سورية)، الطبعة:

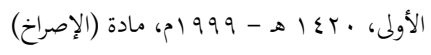
(rآ) ينظر : النسفي، عبد الله بن أحمد، مدارك التنزيل وحقائق التأويل، حققه وخرج أحاديثه: يوسف علي بديوي، دار الكلم الطيب، بيروت، الطبعة الأولى، $|V| / T$

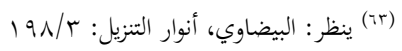

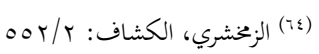

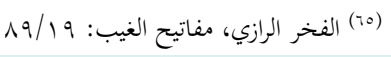




$$
\text { المبحث الثاني: أضراب الخبر }
$$

عرضنا فيما مضى الأغراض التي يلقي لأجلها المتكلم خبره، وعرفنا أن الخبر يخرج أحياناً عن أغراضه الأصلية

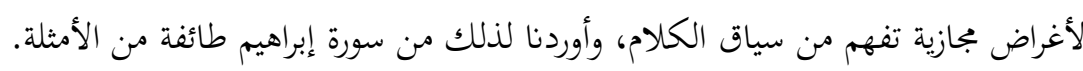

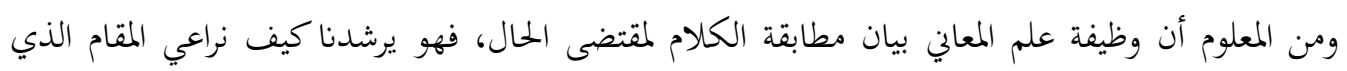

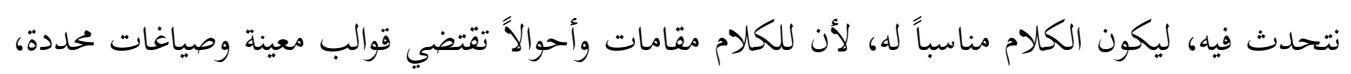

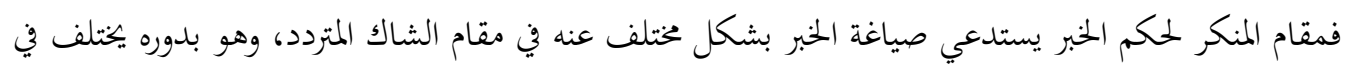

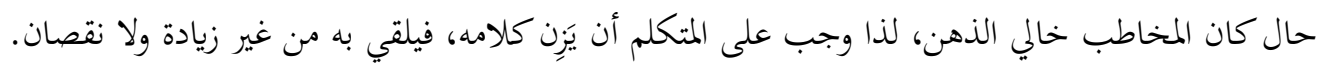

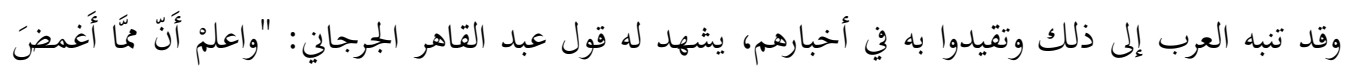

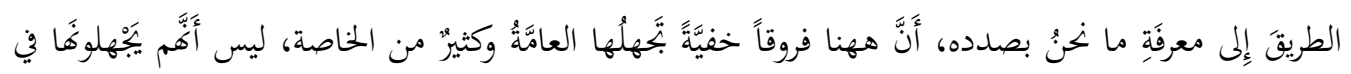

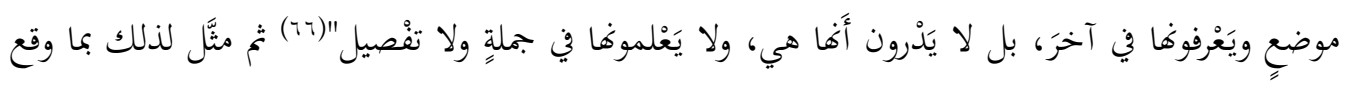

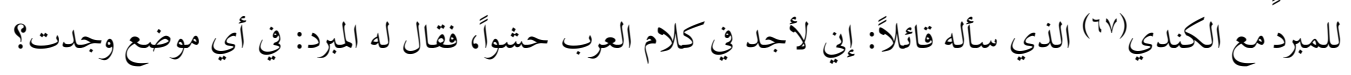

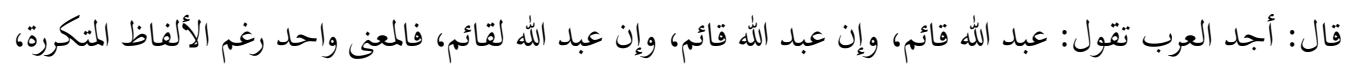

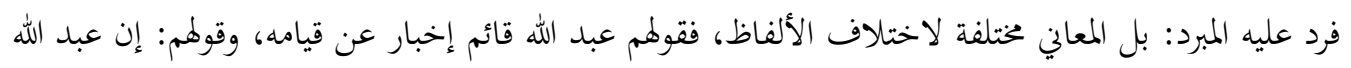

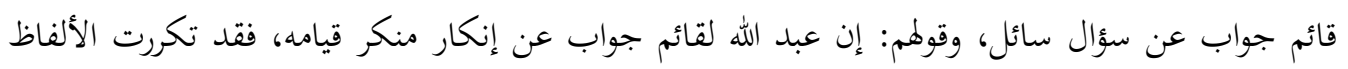
لتكرر المعاني (11).

وبناء على كلام المبرد قسم أهل البلاغة الخبر من حيث تأكيده وعدم تأكيده إلى ثلاثة أقسام أطلقوا عليها (أضراب الخبر) وهي:

(آ1) الجرجاني، عبد القاهر بن عبد الرحم، دلائل الإعجاز في علم المعاني، المحقق: محمود محمد شاكر، مطبعة المدني بالقاهرة - دار المدني بجدة، الطبعة: الثالثة، 10

(†v) هو يعقوب بن إسحاق بن الصباح، كان رأساً في المنطق اليوناني والهيئة والتنجيم والطب، كان يقال له: فيلسوف العرب، قال عنه الذهبي: "كان متهما

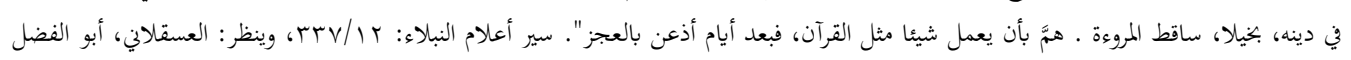

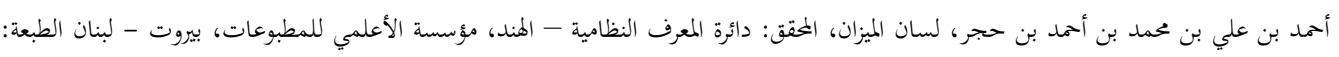

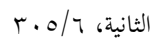
r) ينظر : عبد القاهر الجرجاني، دلائل الإعجاز: 
ويراد به إلقاء الخبر خالياً من أدوات التوكيد، ويلجأ إليه عندما يكون المخاطب خالي الذهن من مدلول الخبر

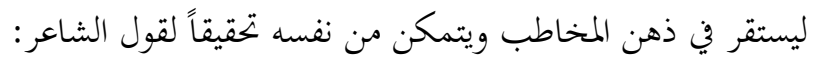

$$
\text { أتاني هواها قبل أن أعرف الموى فصادف قلباً خالياً فتمكنا(v) }
$$

ومن أمثلة هذا الضرب قوله تعالى حكاية عن قول سيدنا إبراهيم: (قالَ بَلْ فَعَلَهُ كَبيرهُهمْ هذا)(ا(V) فالحخبر ألقي

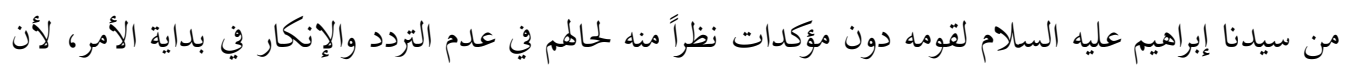
تمحيص ذلك الخبر واختباره استدعى منهم الرجوع إلى نفوسهم والاحتكام إلى عقولهم كما قال تعالى: (فَرَجَعُوا

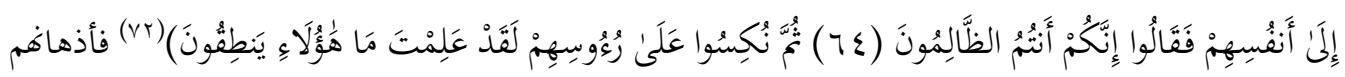

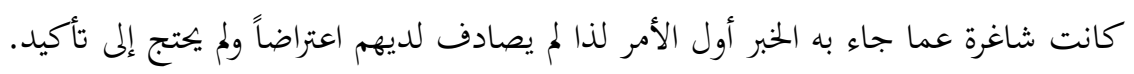

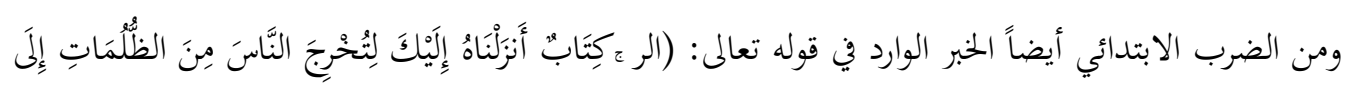

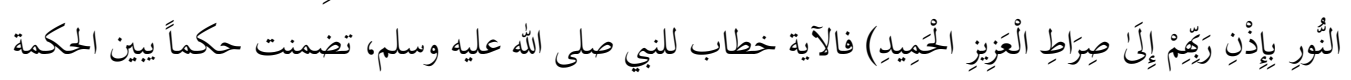

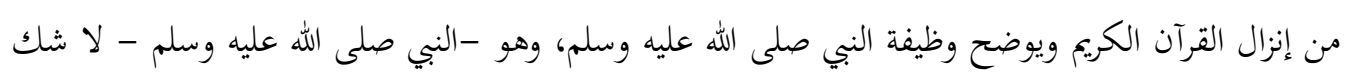

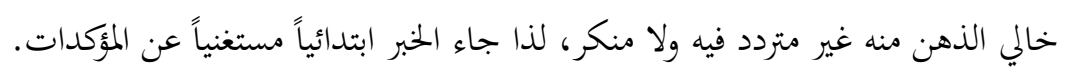

الخبر الطبي (vr)

ويكون حينما يدخل الشك نفس المخاطب ويتردد في قبول الحكم الذي يتضمنه الخخبر، حاله كحال طالب

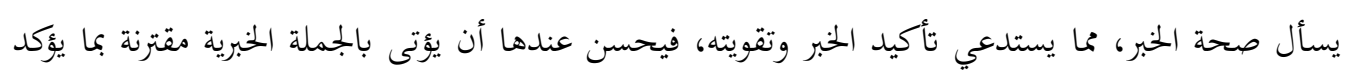

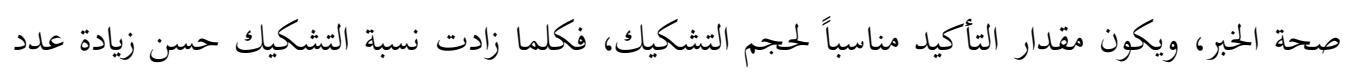
المؤكدات المزيلة ها.

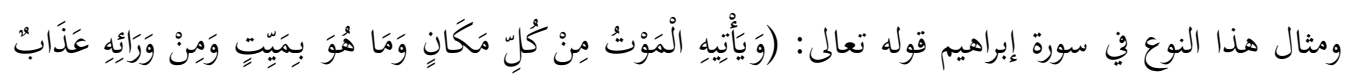

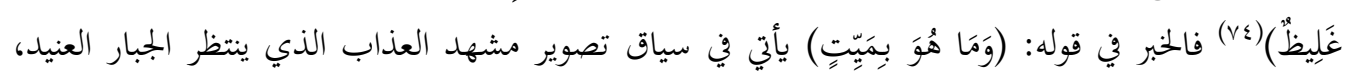

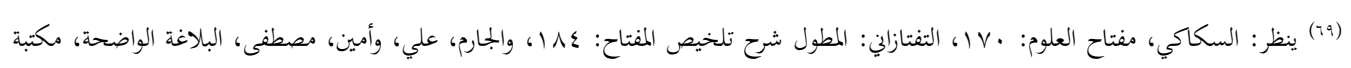

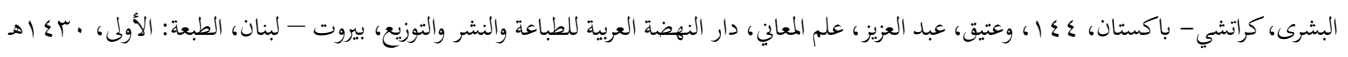
or a r. . . 9 -

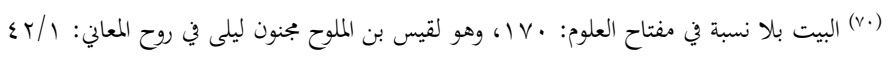

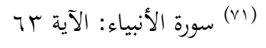
70 سورة الأنبياء: الآينياء: الآية

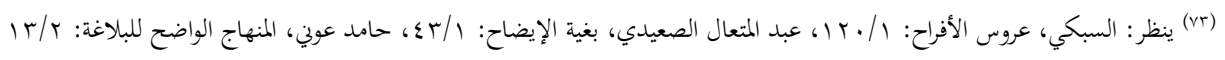

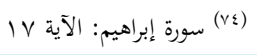


ومعنى قوله تعالى: (وَيَتْنِيهِ الْمَوْتُ مِنْ كُلِّ مَكَانٍ): تتألب عليه أسباب الموت وأصناف العذاب كلها، وتحيط به

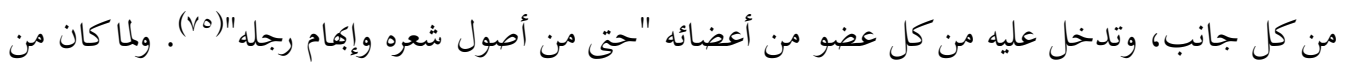

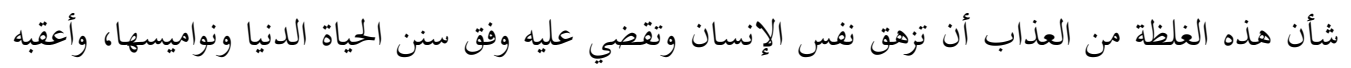

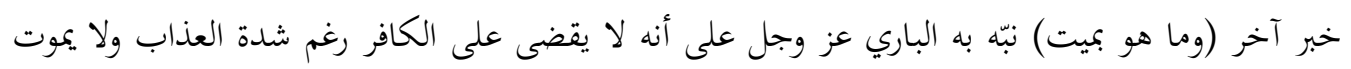

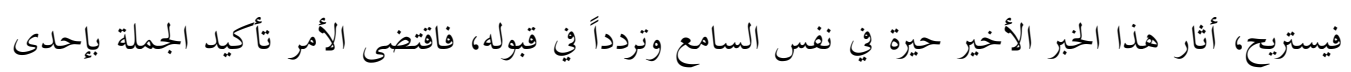

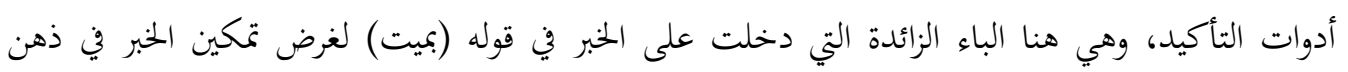
المخاطب وإزالة الشكوك عنه.

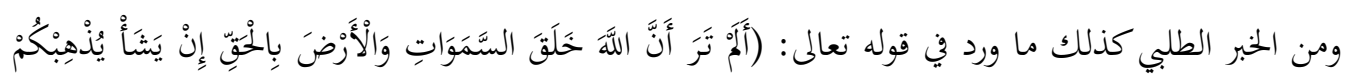

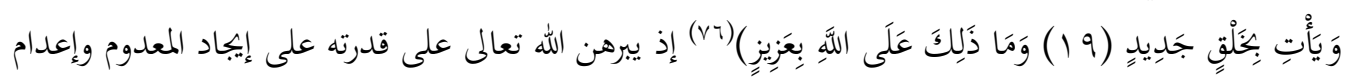

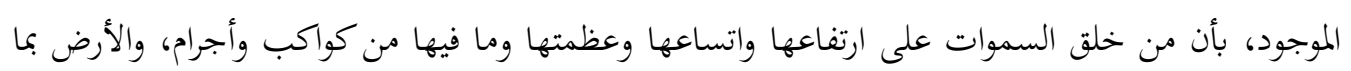

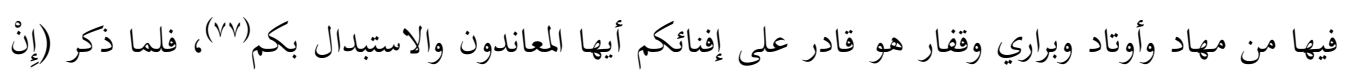

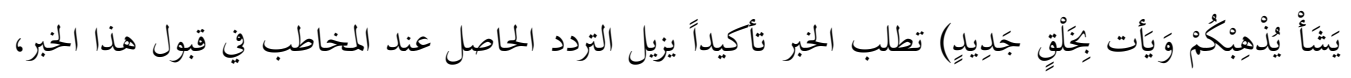

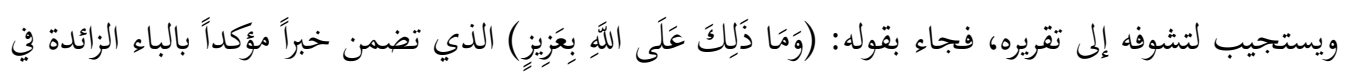
(بعزيز) لترسيخ الحكم وتقويته.

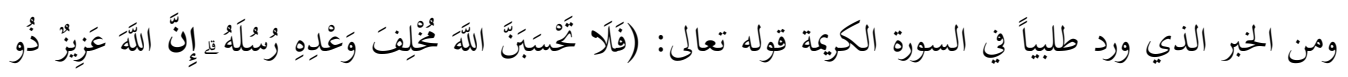

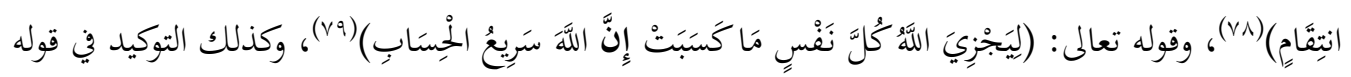

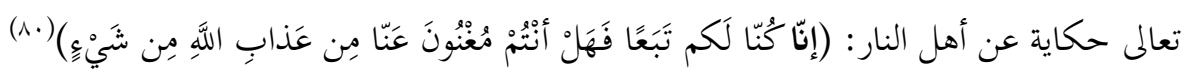

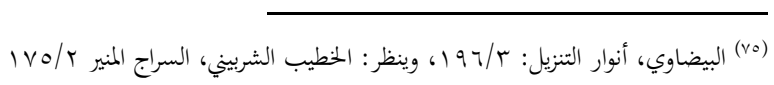

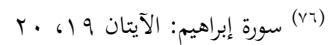

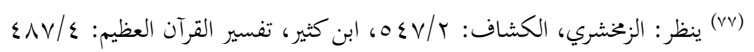

$$
\begin{aligned}
& \text { سورة إبراهيم: الآية VV (V) } \\
& \text { (V9) }
\end{aligned}
$$

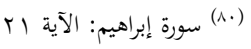


ويلقيه المتكلم حينما يكون المخاطب منكراً للحكم الذي يتضمنه الخبر، معتقداً خلافه، وعندها يجب تأكيد

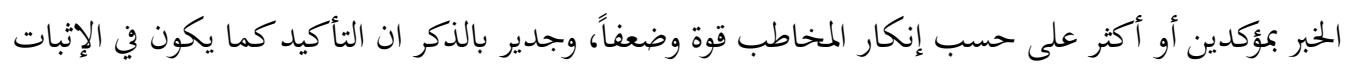
يكون في النفي أيضاً.

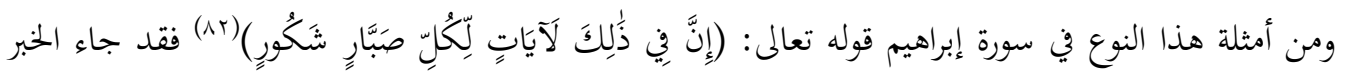

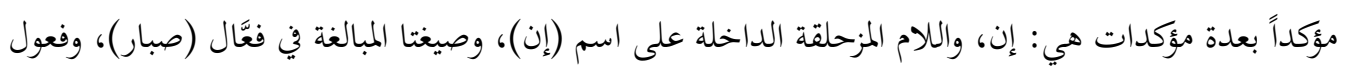

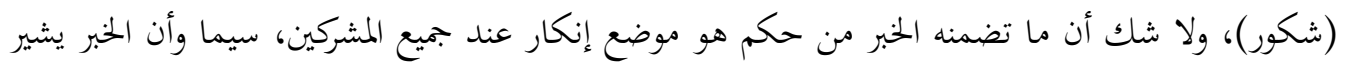

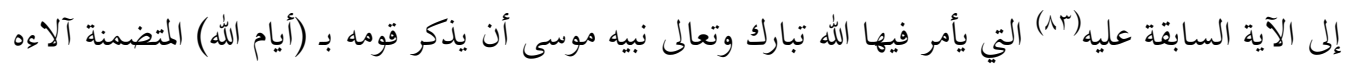

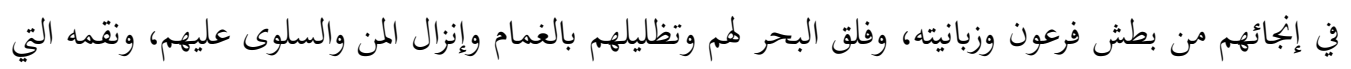

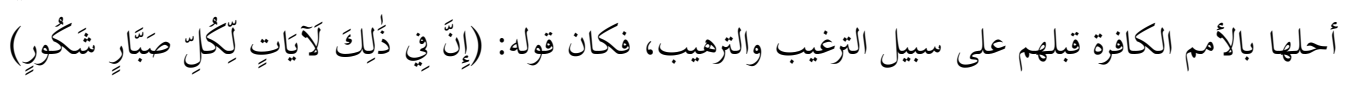

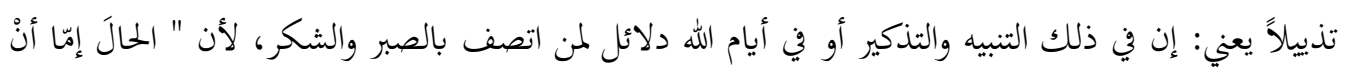

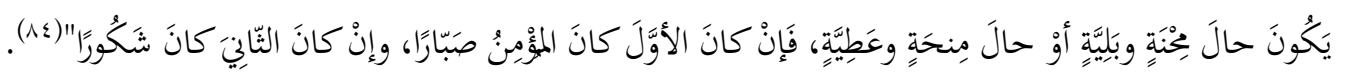
ولكن لقائل أن يقول: إن ما ذكر يصلح أن يكون آيات لكل مؤمن فلما خص الصبار الشكور؟ يجيبنا الفخر الرازي على ذلك بوجهين(^o):

الأول: لما كان الصبار الشكور أكثر المنتفعين هذذه الدلائل، صارت الآيات كأها ليست إلا لهذا النوع، نظير ما

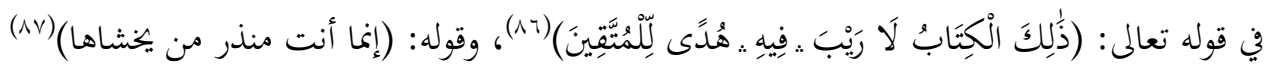
الثاني: إن الانتفاع هذا التذكير لا يكصل إلا لمن اتصف بهاتين الصفتين، أما الذي لا يكون كذلك فهو محروم على عينه عشاوة عن هذه الآيات.

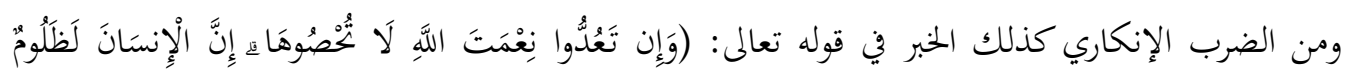

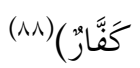

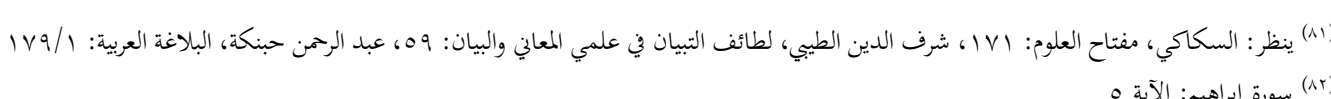

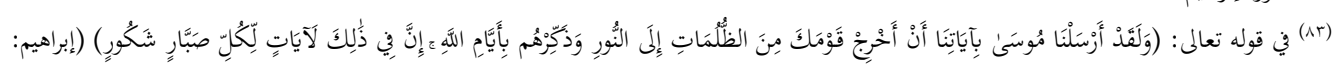

$$
\begin{aligned}
& \text { (1) الفخر الرازي، مفاتيح الغيب: } 9 \text { (10/1) }
\end{aligned}
$$

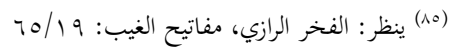

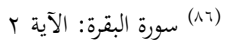

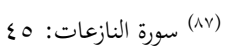

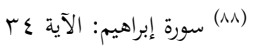


وقد قيل في تفسير ظلوم أنه يظلم النعمة بترك شكرها، أو يضعها في غير موضعها، أو أنه ظالم لنفسه بتعريضها

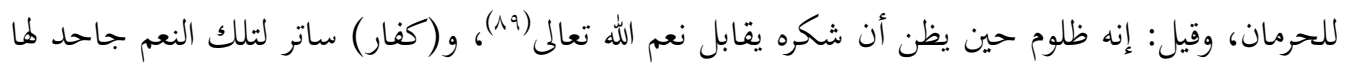

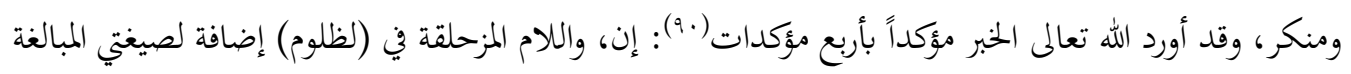
فعول وفعَّال. وجاء إنكارياً لمخالفته اعتقاد المخاطبين من المشركين المتصفين بما تضمنه الخبر من صفيت وكني الظلم والكفران.

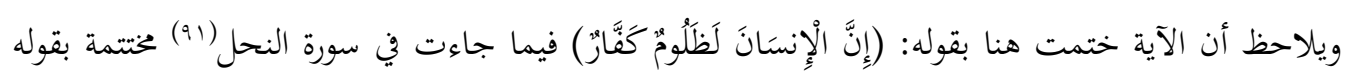

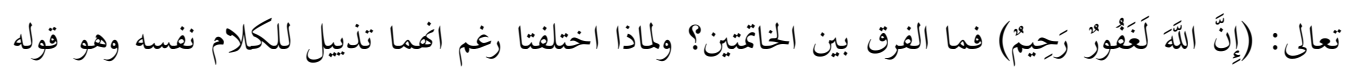

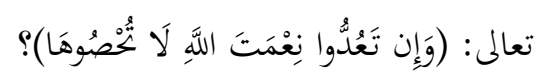

يجيبنا عن ذلك سياق الآيتين، فلما كان الحديث هنا عن قبائح الإنسان من كفران للنعمة وجحود لها وظلم

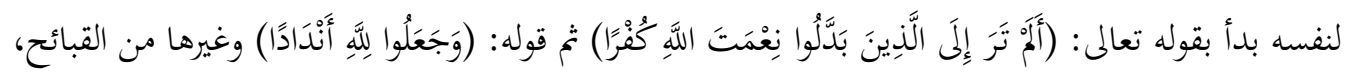

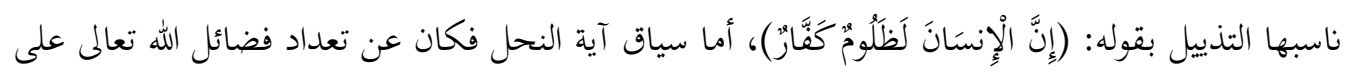
الإنسان(T)، وبعد أن أطنب في ذكرها حسن التذييل بوصف الله تعالى بالمغفرة والرحمة حضاً للناس وتحريضاً لهم على الرجوع إليه تعالى( (9r).

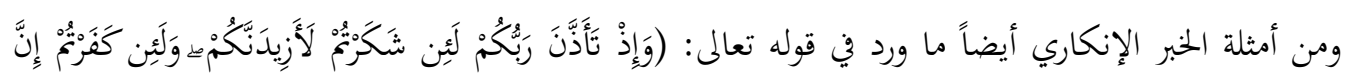

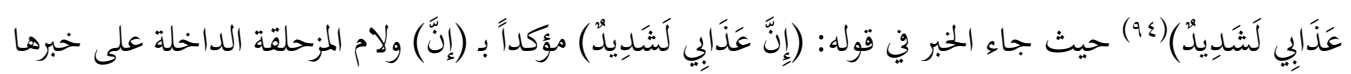
إضافة إلى اسمية الجملة(90).

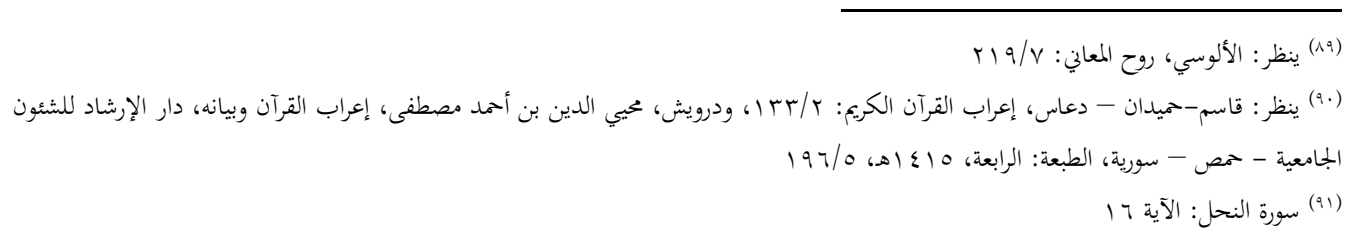

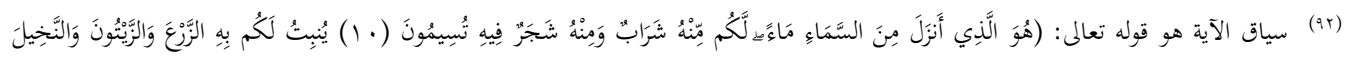

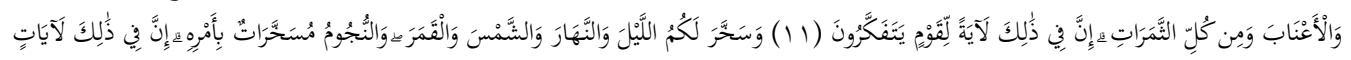

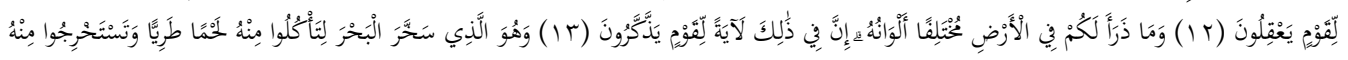

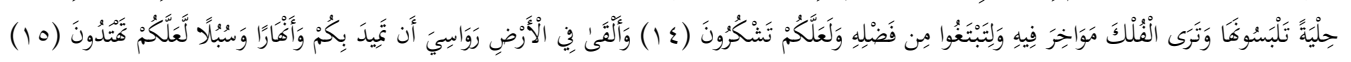

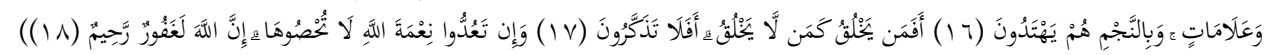

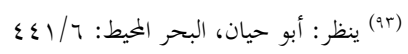

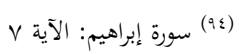

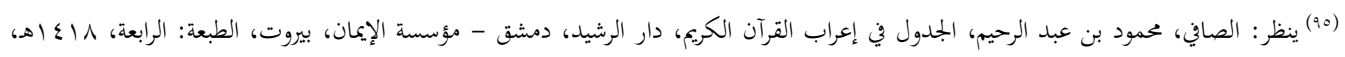
$109 / 11$ 


$$
\text { ولكعلماء في جملة (إِنَّ عَذَابِي لَشَدِيدُّ) قولان(9T): }
$$

الأول: إنا خبر سد مسد جوابي القسم والشرط في قوله: (ولئن كفرتم) بمعنى: لئن كفرتم وجحدتم إنعامي عليكم

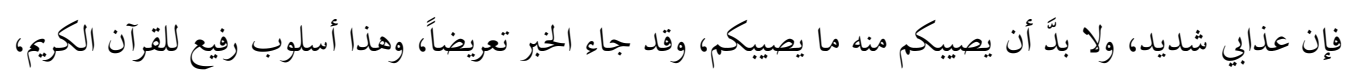

$$
\text { إذ من عادة الكرام التصريح بالوعد والتعريض بالوعيد. }
$$

الثاني: إن جملة جواب (ولئن كفرتم) محذوفة تقديرها (لأعذبنكم) والحخبر في قوله: (إِنَّ عَذَابِي لَشَدِيدُّ) جاء تعليلاً لها، وقد احتاج الخبر للتأكيد كونه موجهاً لمن ينكره ولا يعبأ به، بل ولا يعتقده أصلاً.

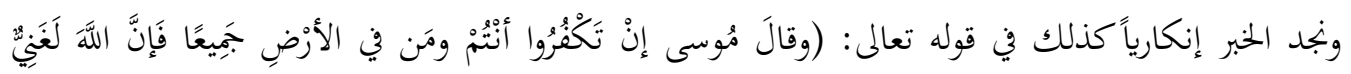

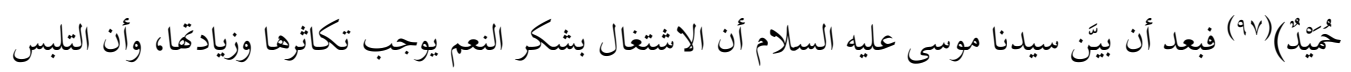

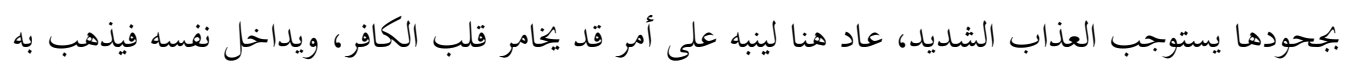

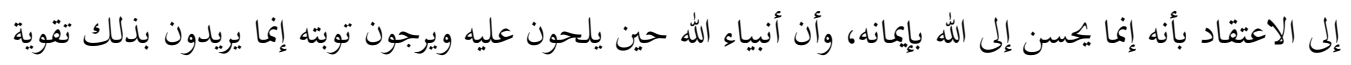

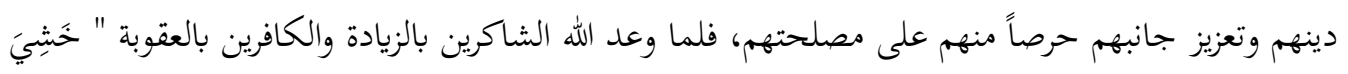

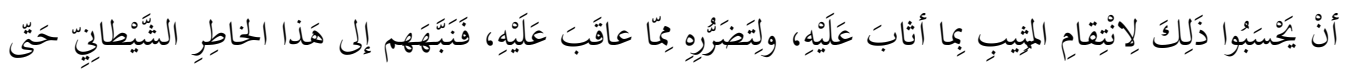

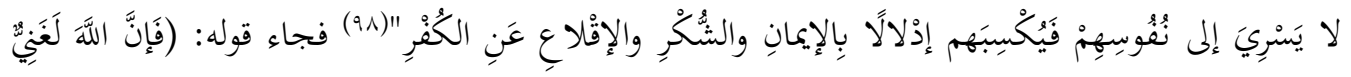

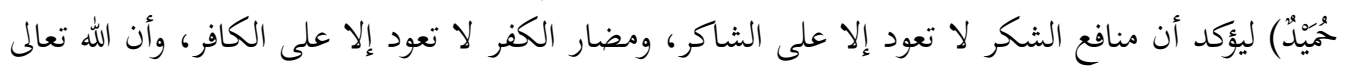
غني: وهو الذي لا حاجة له في شيء. ويدخل في عموم غناه أنه غني عن الذين يكفرون، وأنه حميد: محمود

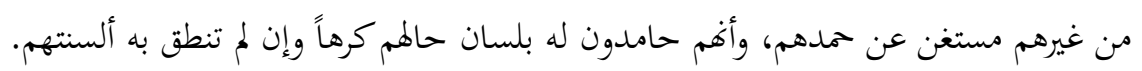
وكما نلاحظ فإن الخبر جاء مؤكداً بـ (إن)، واللام المزحلقة إضافة إلى اسمية الجملة، والذي استدعى تأكيده أن

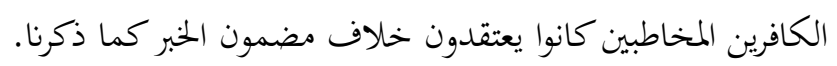

ومن الضرب الإنكاري ما جاء على لسان الأقوام البائدة قوم نوح وعاد وثمود حين سعى رسلهم في هدايتهم

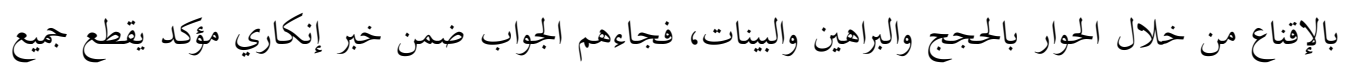

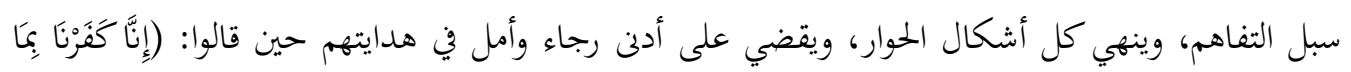

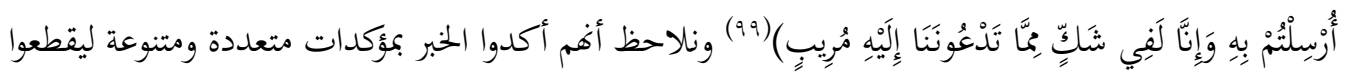

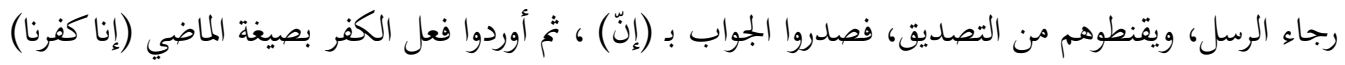

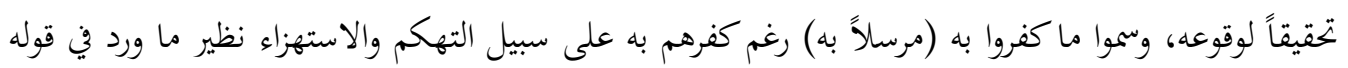

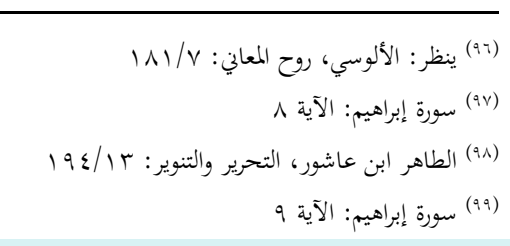


I İbrahim Suresinde Haber Üslubunun Belagati/ The Rhetoric of al-Khabar in Surat al-Ibrahim

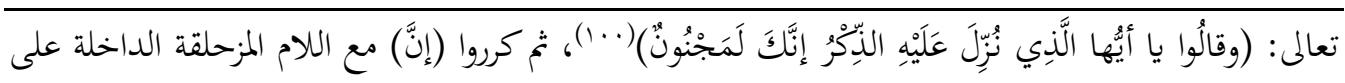

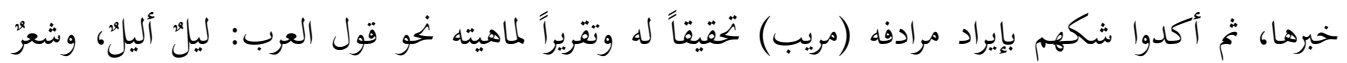

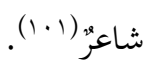

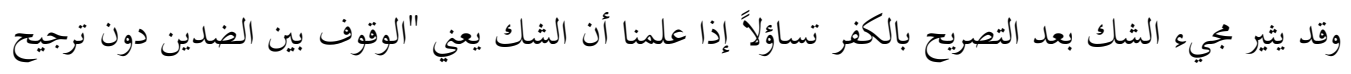

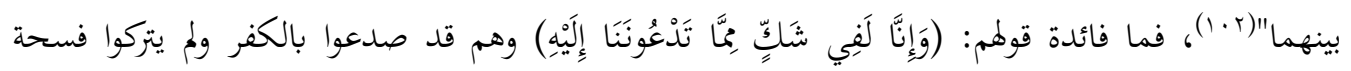

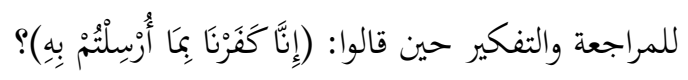
أجاب عن ذلك الطاهر بن عاشور بما مفاده(r.1): أن كفرهم كان موجهاً إلى نسبة دعوة الرسل إلى الله تعالى،

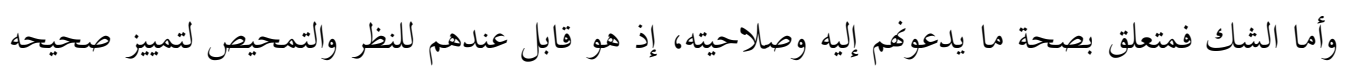

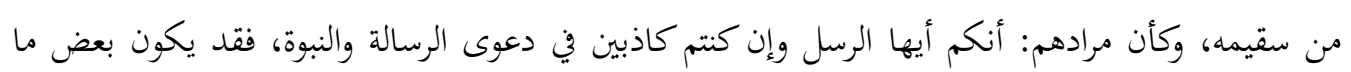
تدعون إليه حقاً لأن الكاذب لا يعدم صدقه أحياناً.

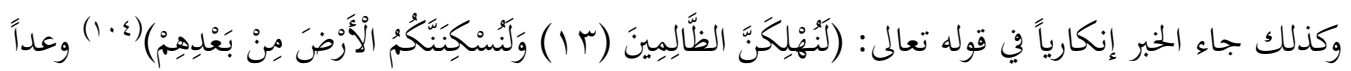

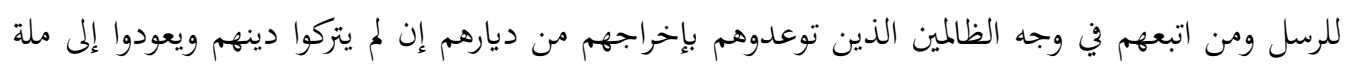

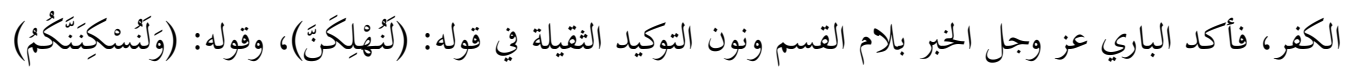

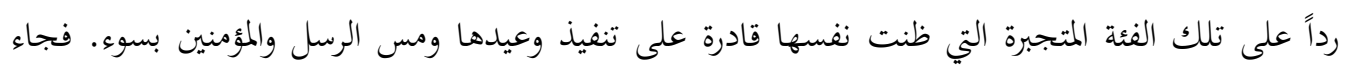

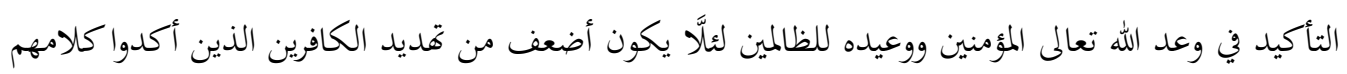

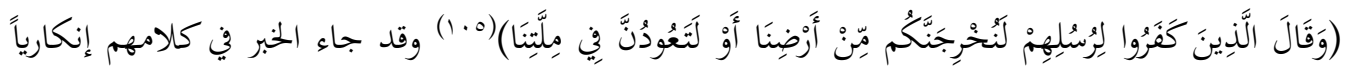

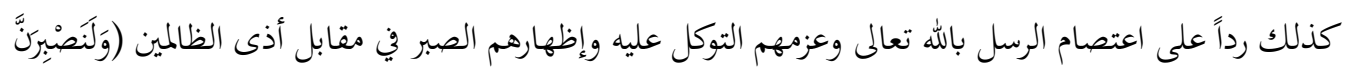

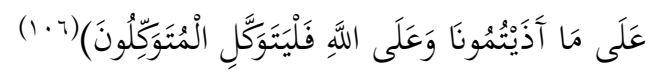

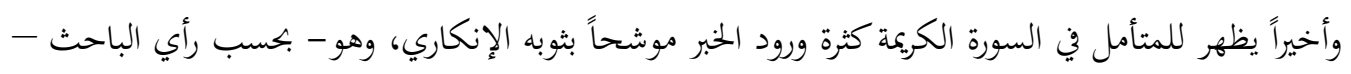

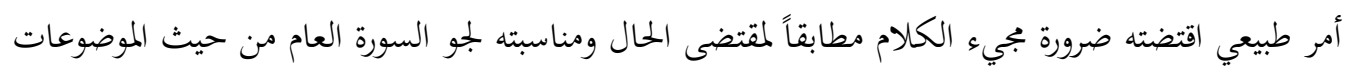

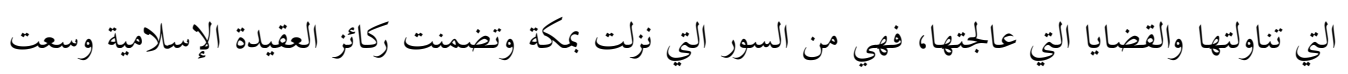

$$
\begin{aligned}
& \text { (1..) }
\end{aligned}
$$

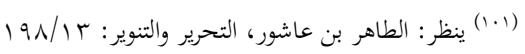

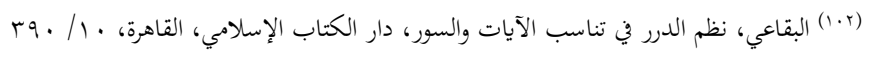

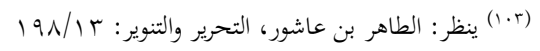

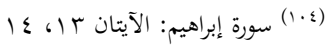

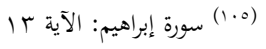

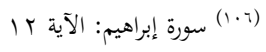


إلى تثبيتها وترسيخا، ولما كانت الحقائق التي انطوت عليها هذه العقيدة موضوع إنكار وجحود، ومحور جدل

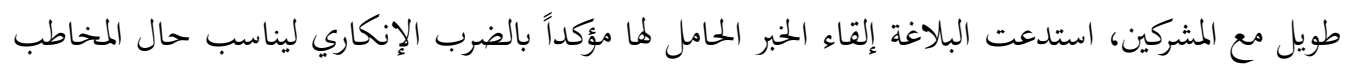
ومقام الحديث.

\section{المبحث الثالث: خروج الحبر على مقتضى الظاهر}

قد يجري المتكلم خبره على خلاف الظاهر من حال المخاطب، فلا يعتد في صياغته بما سبق من الأحوال، وإنما

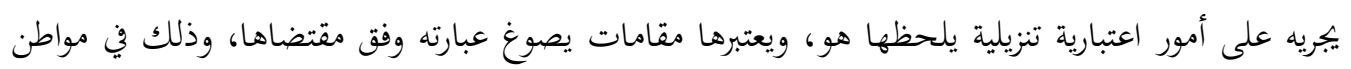
دقيقة لا يهتدى إليها إلا بعد طول نظر و تأمل، منها: تنزيل خالي الذهن منزلة السائل المتردد

ويكون ذلك عندما تتضمن الجمل السابقة على الخبر إثارات أو أيماء يثير في نفس السامع تساؤلاً فيأتي الخبر

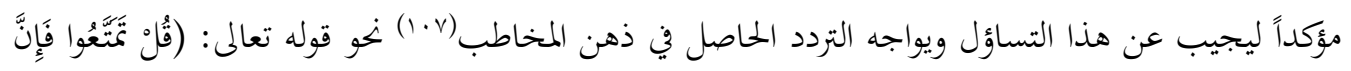

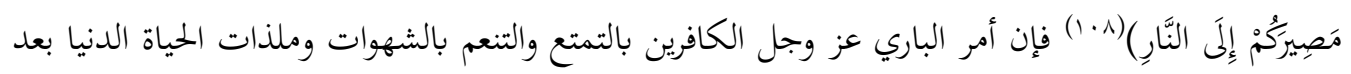

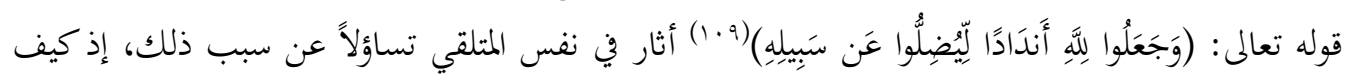

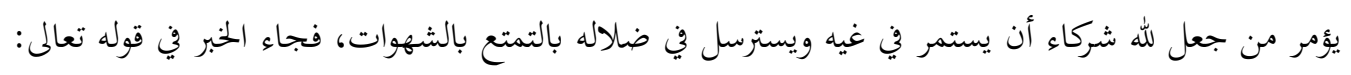

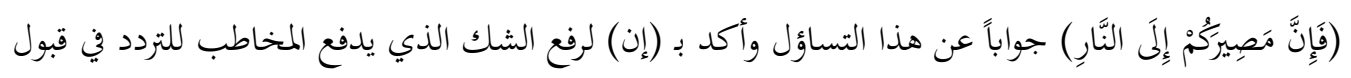

هذا التعليل.

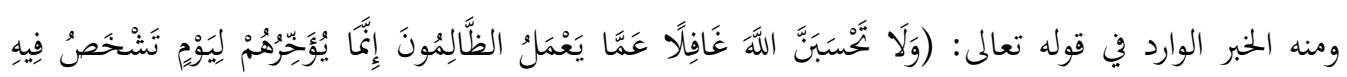

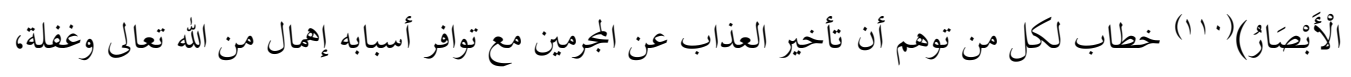

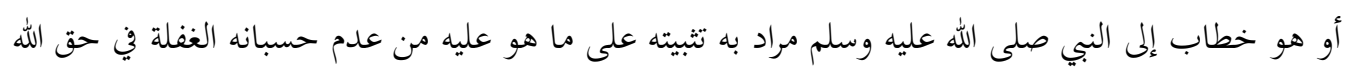
تعالى، وهذا الخطاب جار على سبيل التسلية للمظلوم والتهديد للظالم. وقد أكد البيان الإلهي الخبر بـ (إنما) ليقع موقع الجواب المؤكد عن تساؤل قد يثيره في ذهن المخاطب قوله تعالى

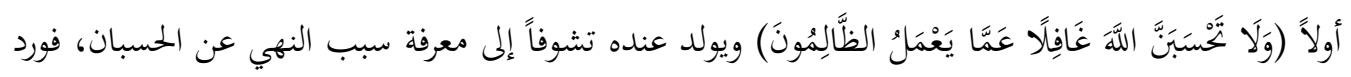

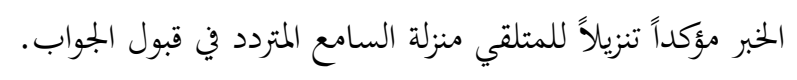

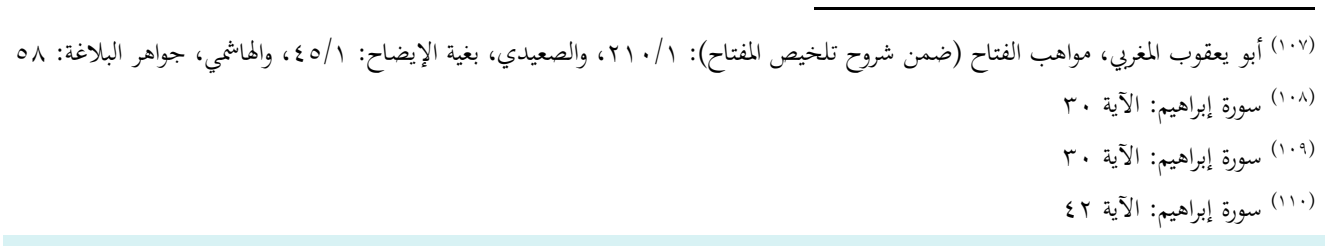


İbrahim Suresinde Haber Üslubunun Belagati/ The Rhetoric of al-Khabar in Surat al-Ibrahim

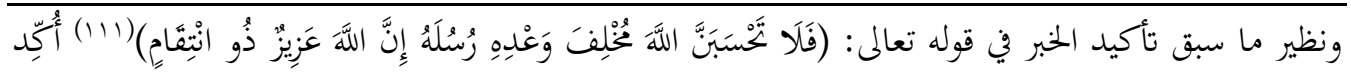

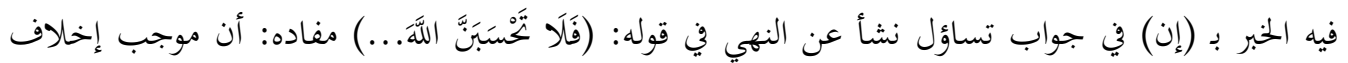

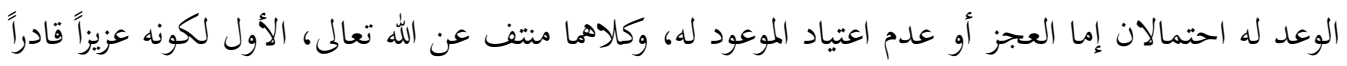

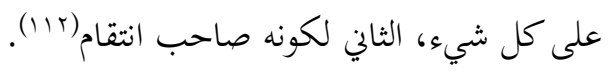
تنزيل منكر الخبر منزلة غير المنكر

ومن ضروب الخخروج على مقتضى الظاهر تنزيل منكر الخبر منزلة غير المنكر لعدم الاعتداد بإنكاره، وافتقاره

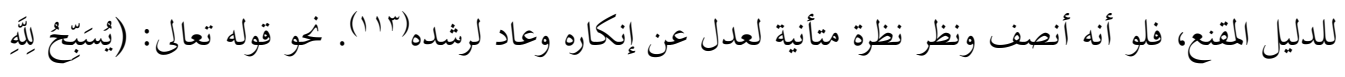

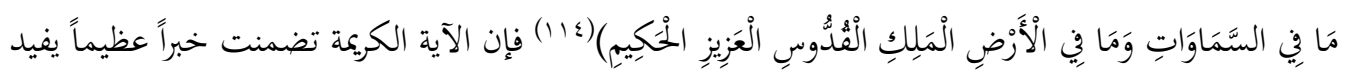

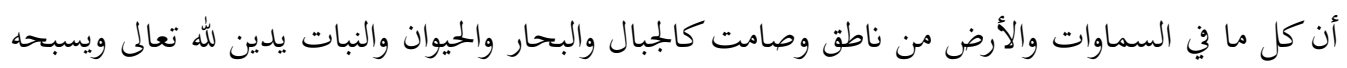

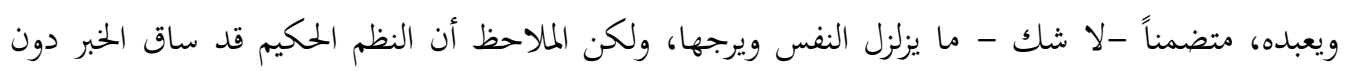
توكيد أو احتفال رغم كونه منكوراً عند الجاحدين (110)

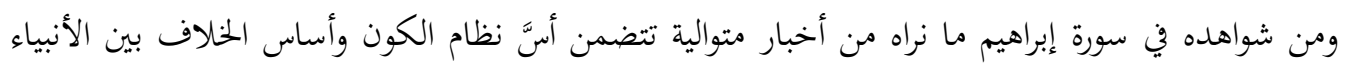

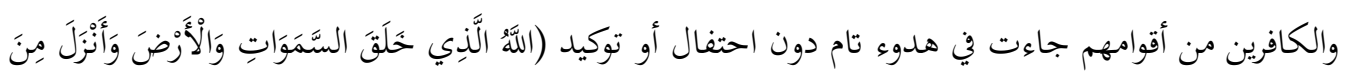

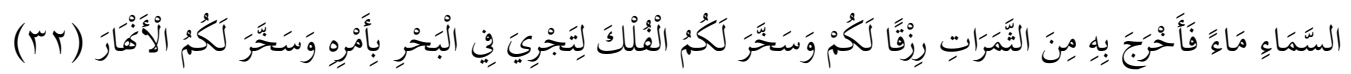

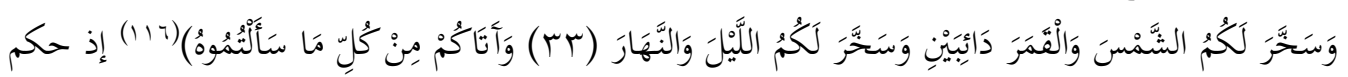

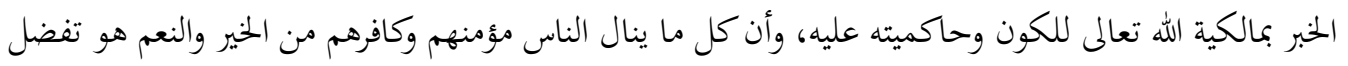

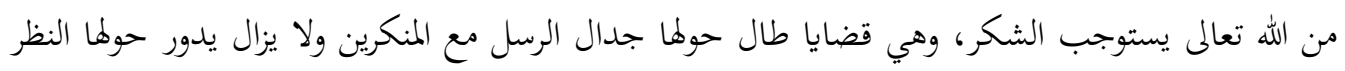
وبتهد فيها العقول وينكرها المنكرون.

ولكن الملمِفت للباحث أن الحكيم آثر الترفع عن جهالة المنكرين، فلم يلتفت إلى إنكارهم ولم يعباً به، لأن الكون الكون

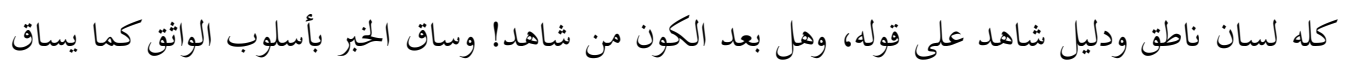

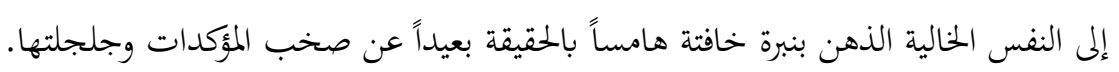
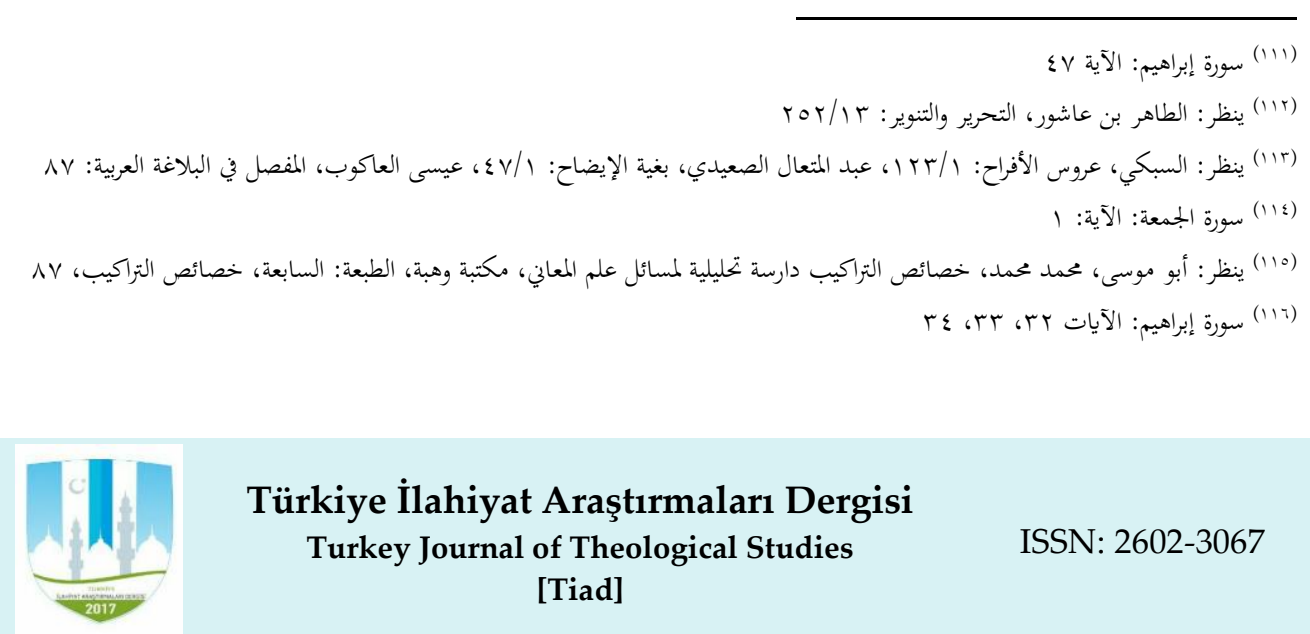


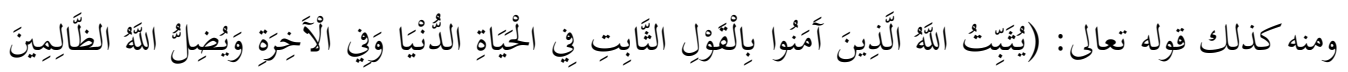

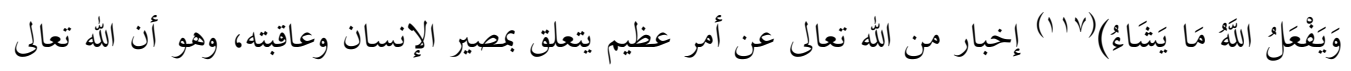

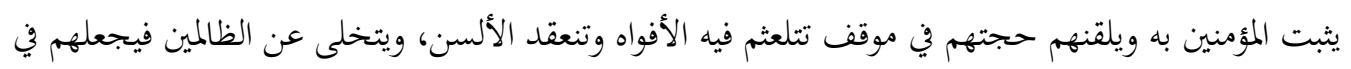

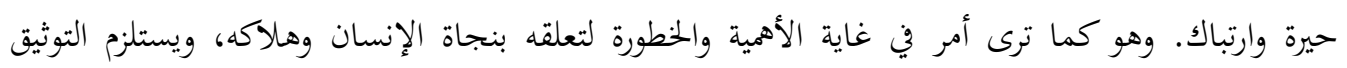

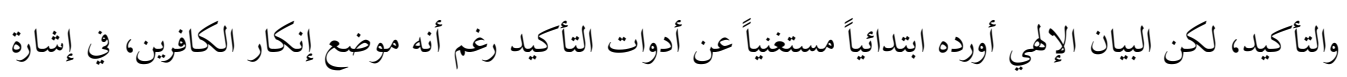
إلى عدم اعتباره واعتداده بإنكار المنكرين.

\section{تنزيل غير المنكر منزلة المنكر}

ويكون عند ظهور أمارات الإنكار على المخاطب فيستدعي ذلك خروجاً على الظاهر مراعاة لتلك ألك

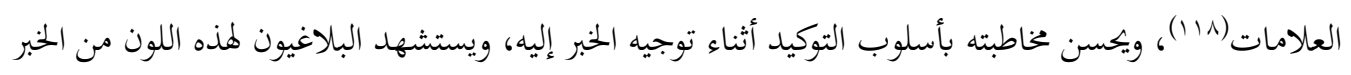

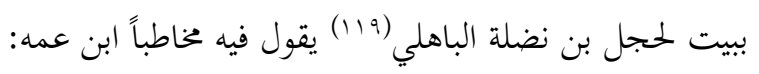

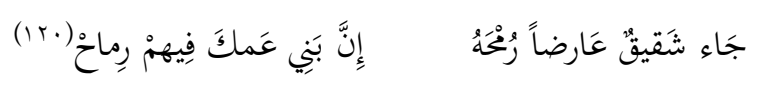

فالشاعر حينما رأي شقيقاً قد أقبل هيئة تظهر عدم اكتراثه بالقوم، واضعاً رمحه على فخذيه عرضاً، عدَّ ذلك

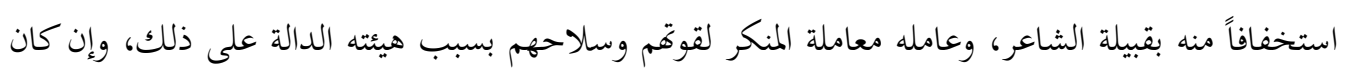

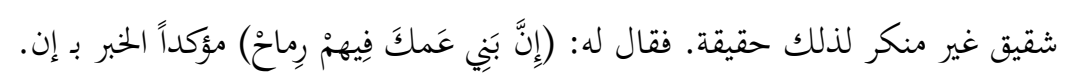

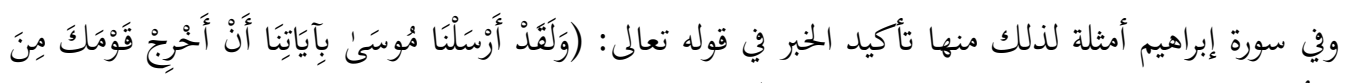

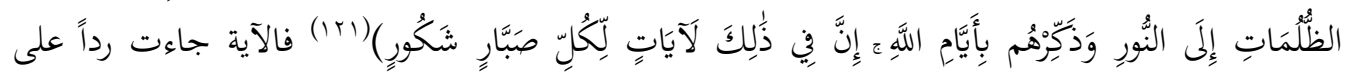

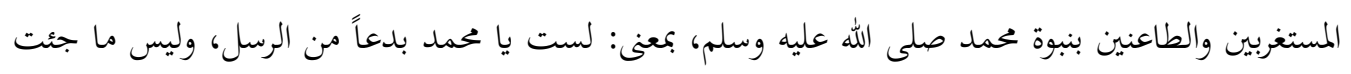

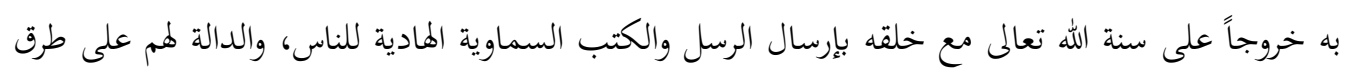

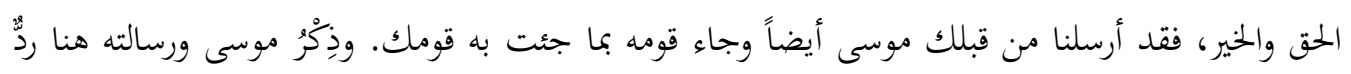

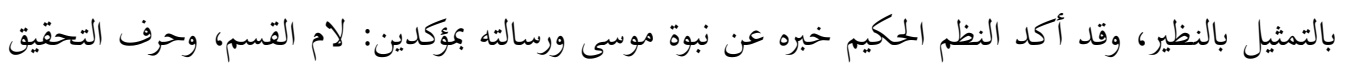

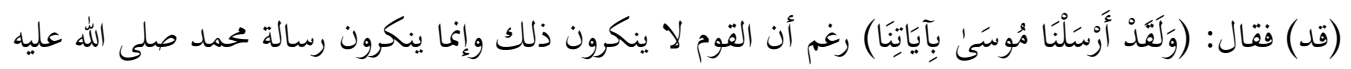

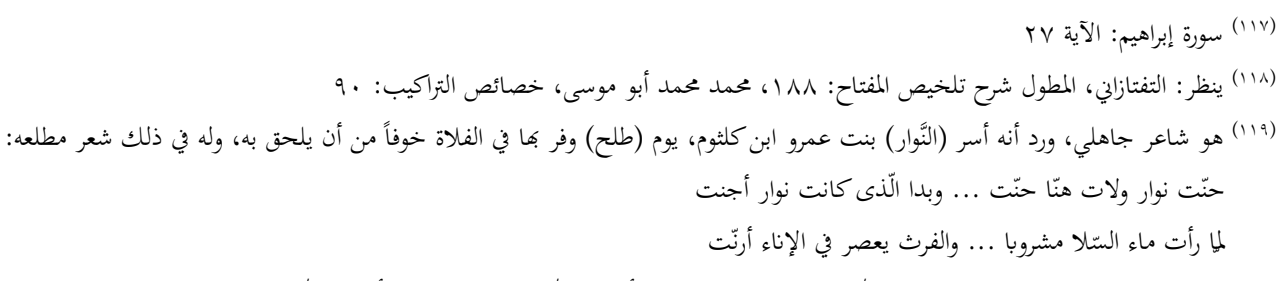

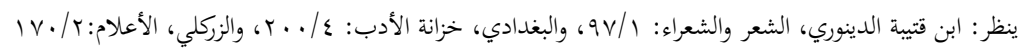

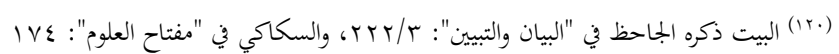

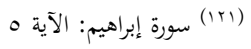

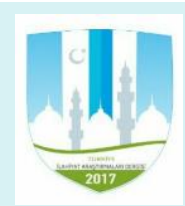




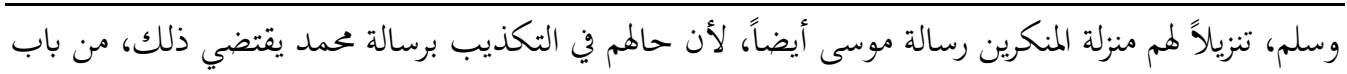

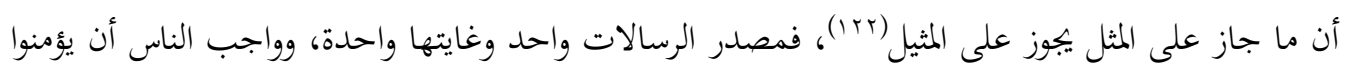
بها جميعها دون تفريق.

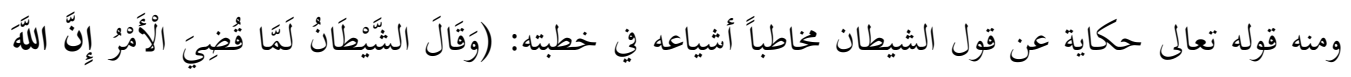

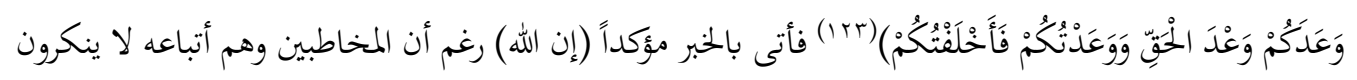

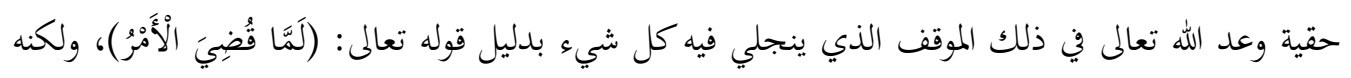

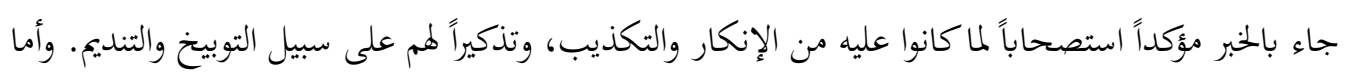

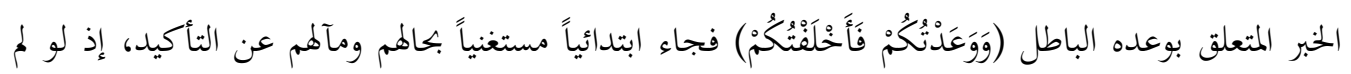
يخلفهم لما اجتمعوا معه في هذا الموقف المهين.

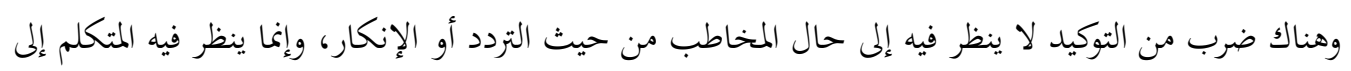

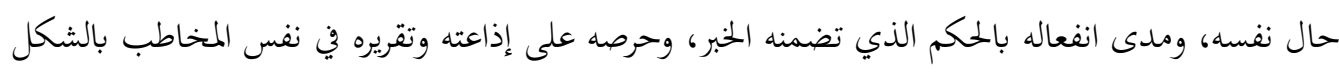

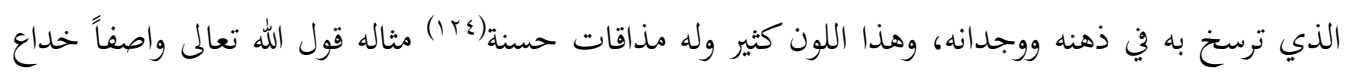

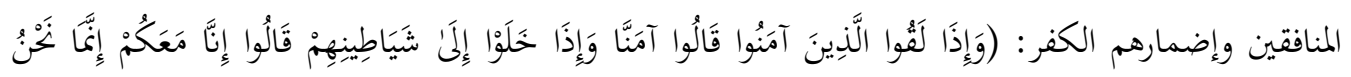

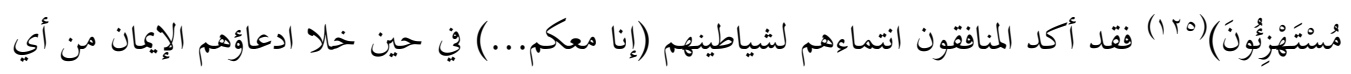

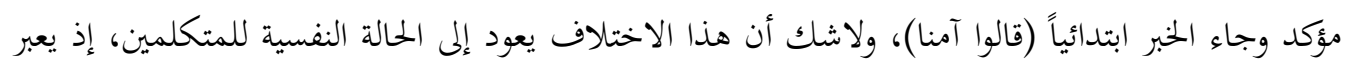

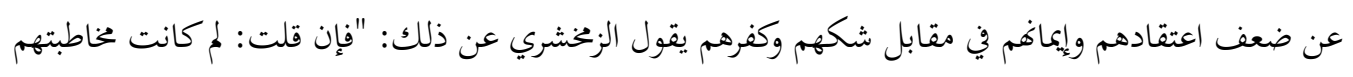

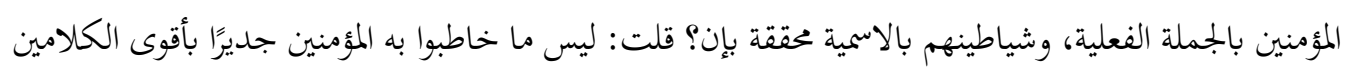

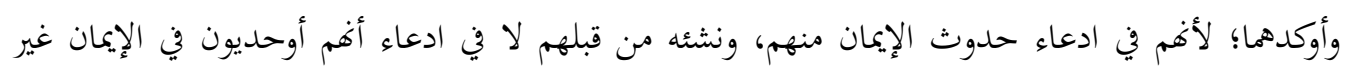

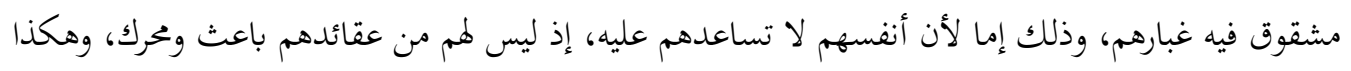

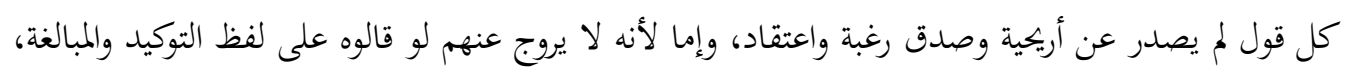

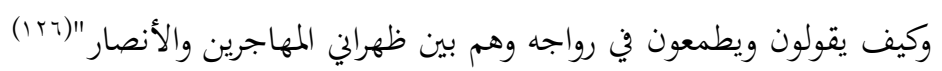
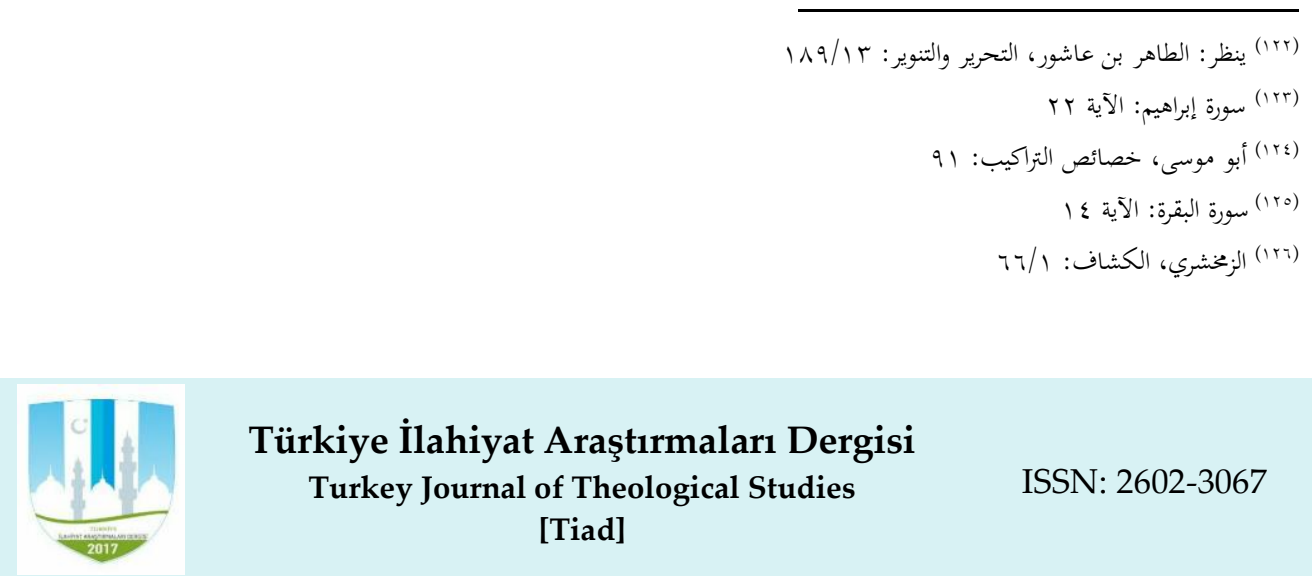
ومن هذا الضرب التوكيد في قول سيدنا إبراهيم عليه السلام متضرعاً إلى الله تعالى: (رَبَّنَا إِيّّ أَسْكَنْتُ مِنْ ذُرِيَّيَّي

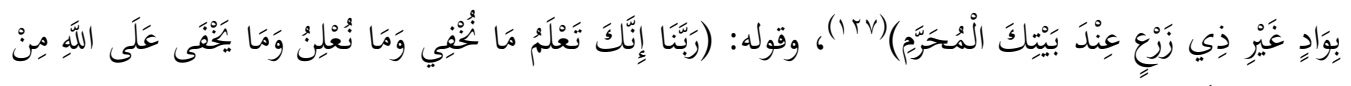

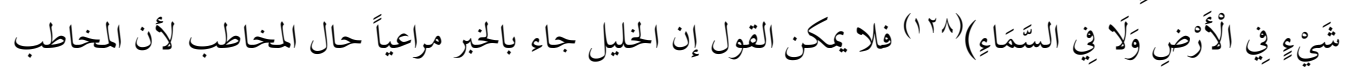

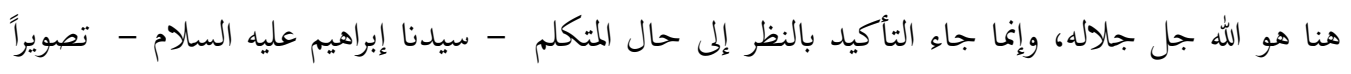

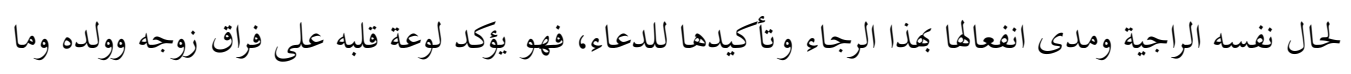

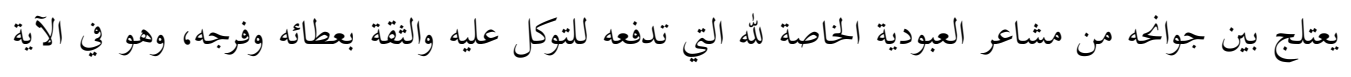

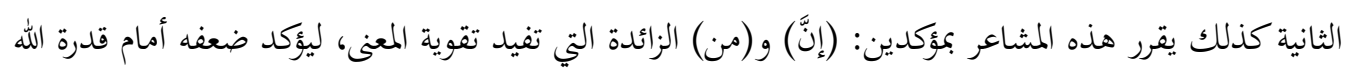
تعالى المخيط بكل شيء علماً وافتقاره الدائم إلى عونه وإحسانه. وهو يخاطب ربه في آية أخرى مؤكداً مشاعر الأسف والحزن التي تعصف به على أولئك المغفلين الذين وقعوا في

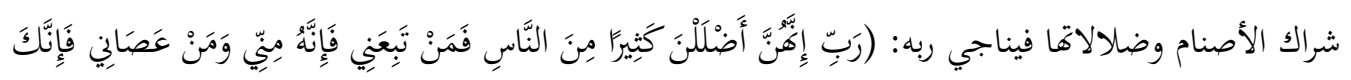

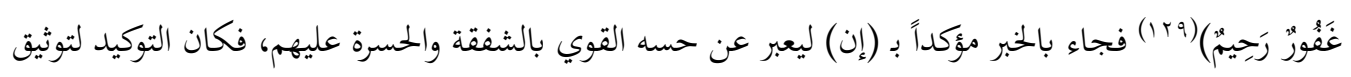
الحالة الوجدانية للمتكلم وتقريرها بأقوى تعبير.

الخاتمة

$$
\text { ظهر للباحث في هاية هذا البحث }
$$

1. كثر خروج الخبر في سورة إبراهيم على غرضيه الأساسيين: فائدة الخبر ولازم الفائدة إلى أغراض بلاغية متنوعة ليواكب أحداث السورة ويكون منسجماً مع الموضوعات التي تناولتها، فورد متضمناً غرض الامتيه الامتنان

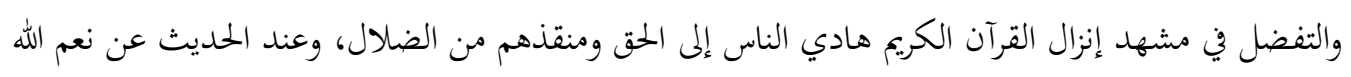

$$
\text { وآلائه على البشر. }
$$

r. الاحظ الباحث تغير المعنى البلاغي المراد بالحبر مع انتقال البيان الإلمي إلى الحديث عن الظالمين

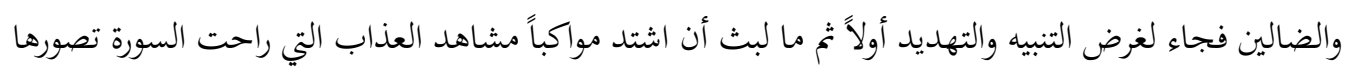

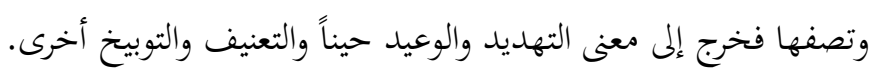

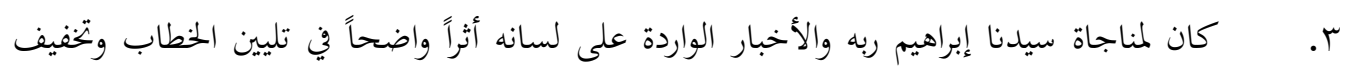

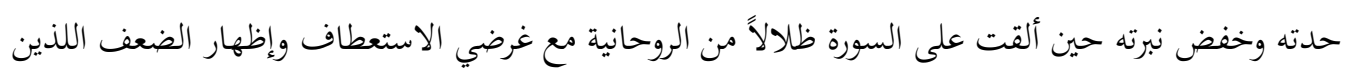

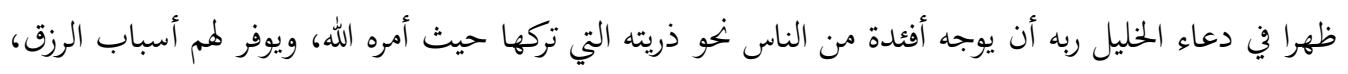

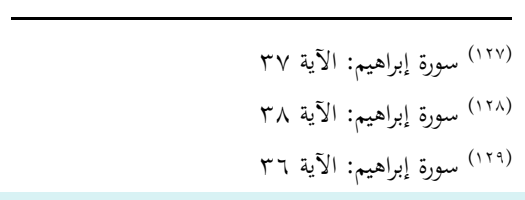


وأرخت على المشهد كذلك مسحة من السكن مع غرض السرور والبهجة الذي برز في طيات خبر الخنليل

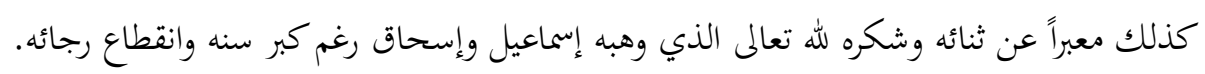

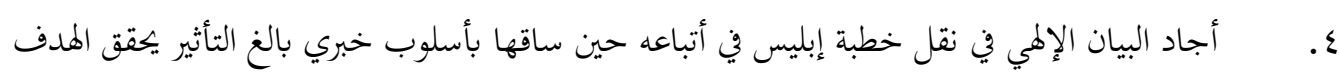

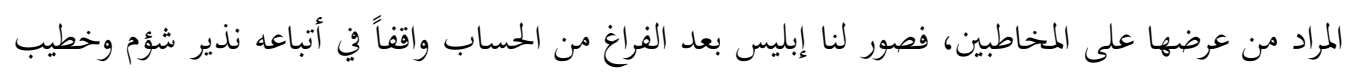

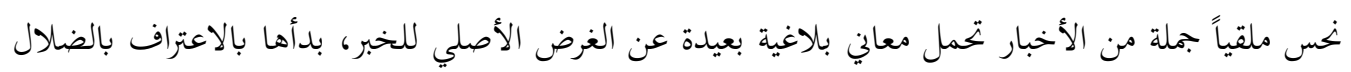

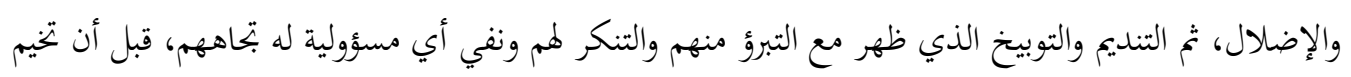

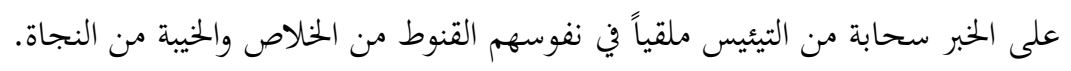

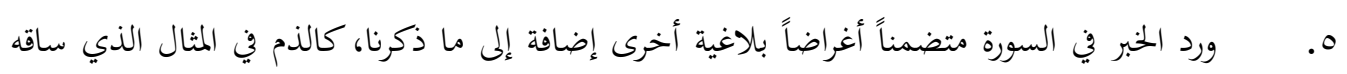

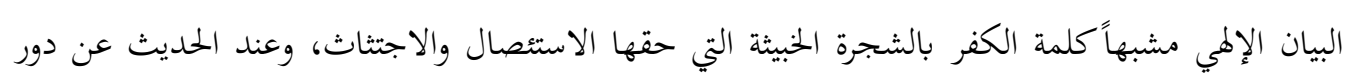

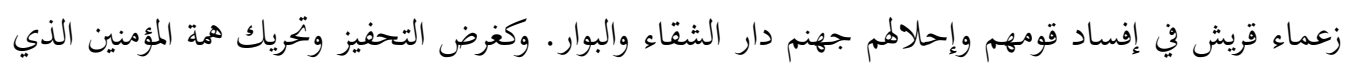
ورد في الأخبار التي وصفت نعيم الجنة تشجعاً لهم على مزيد من الطاعات والمسارعة في الخيرات.

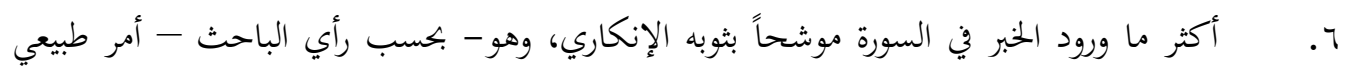

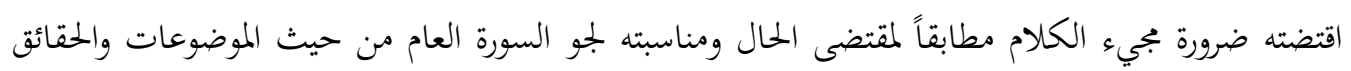

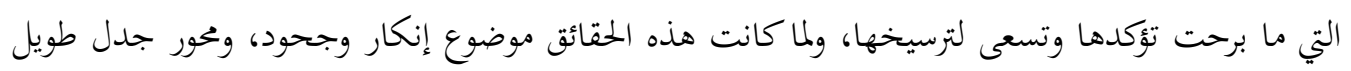

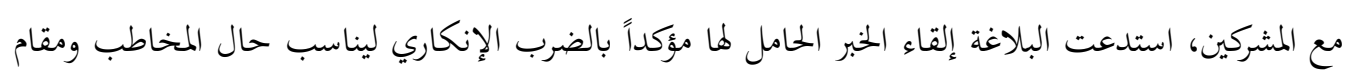
الكام.

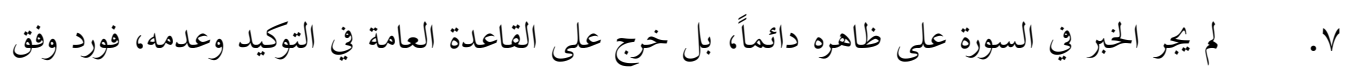

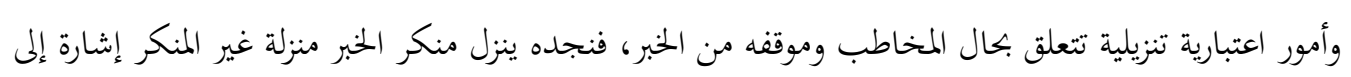
عدم اعتداده بالإنكار، ويسوق الخبر

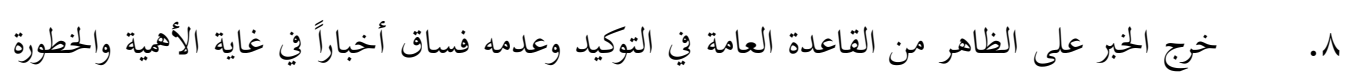

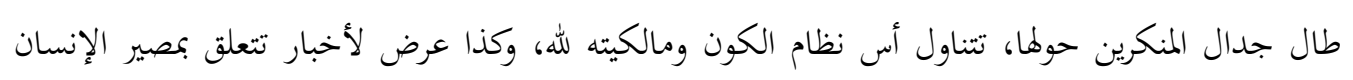
ونجاته أو هلاكه، وكل ذلك بأسلوب هادئ بعيد عن صخب المؤكدات وجلجلتها غير محتفل بالمنكرين ولا عابئ معتقداتم وأفكارهم. 9 . يظهر للباحث أن في ذلك ترفعاً من الله الحكيم عن جهالات المنكرين وضلالاتم اكتفاء بما بث في

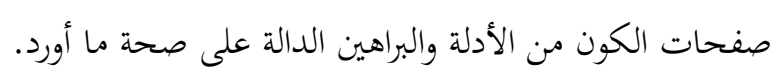

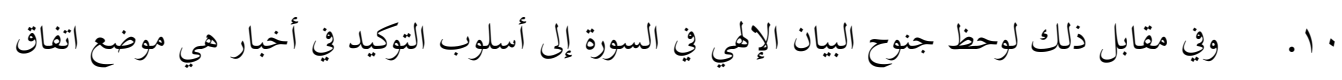

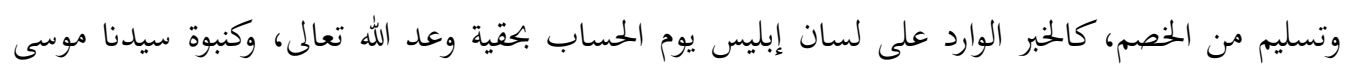

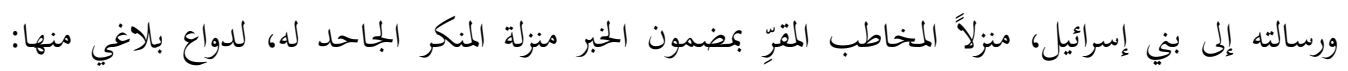


استصحاب حال المخاطبين لما كانوا عليه قبل انجلاء الحق وبزوغه توبيخاً لهم وتنديماً على ما كان منهم، ومنها ظهور أمارات على المخاطبين تنذر بالإنكار وتقتضيه كموقف المنكرين محمد صلى الله عليه وسلم والمقر بها لميدنا موسى.

لم تكن جميع الأخبار الواردة في السورة وفقاً لحال المخاطب بل منها ما كان

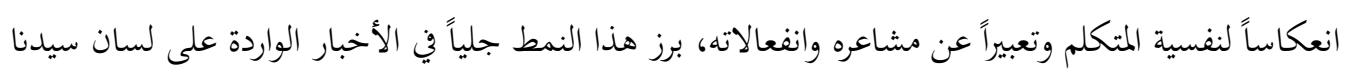

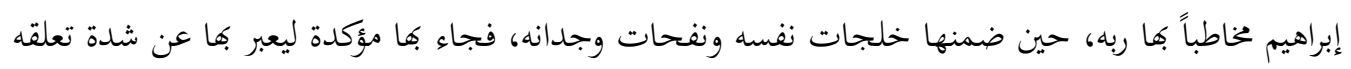
بزوجته وذريته ويقرر الهواجس التي كانت تعصف به بهن قلقاً عليهم. 
ابن أبي طالب، مكي حمّّش بن محمد بن مختار القيسي القيرواني، و جع اهـ - م . . rم، الهداية إلى بلوغ النهاية

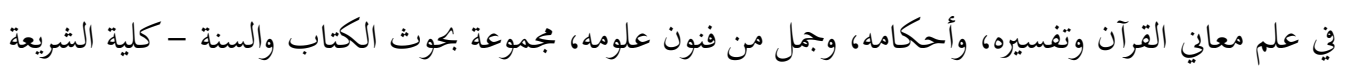

$$
\text { والدراسات الإسلامية - جامعة الشارقة، الطبعة: الأولى. }
$$

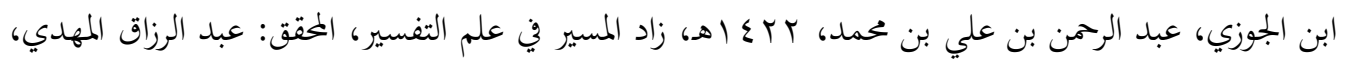
دار الكتاب العربي - بيروت، الطبعة: الأولى.

ابن جزي، أبو القاسم، محمد بن أحمد بن محمد بن عبد الله، التسهيل لعلوم التنزيل، المحقق: الدكتور عبد الله

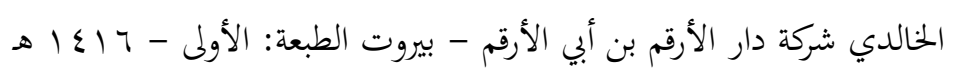

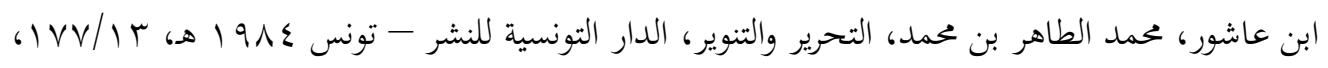

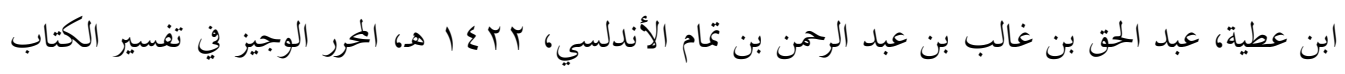
العزيز، المحقق: عبد السلام عبد الشافي محمد، دار الكتب العلمية - بيروت، الطبعة الأولى.

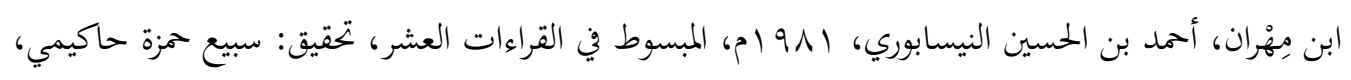
مجمع اللغة العربية - دمشق. ابن هشام، عبد الله بن يوسف بن أحمد بن عبد الله ابن يوسف، أوضح المسالك إلى ألفية ابن مالك، المحقق: يوسف الشيخ محمد البقاعي، دار الفكر للطباعة والنشر والتوزيع.

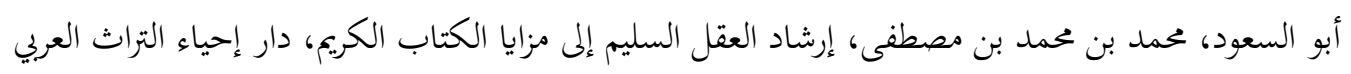
- بيروت

أبو حيان، محمد بن يوسف بن علي بن يوسف، ·بأاه، البحر المحيط في التفسير، المحقق: صدقي محمد

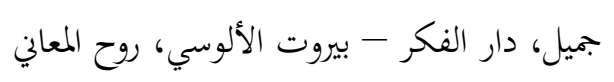

أبو موسى، محمد محمد، خصائص التراكيب دارسة تحليلية لمسائل علم المعاني، مكتبة وهبة، الطبعة: السابعة. الإيجي، محمد بن عبد الرحمن بن محمد، جامع البيان في تفسير القرآن، دار الكتب العلمية - بيروت، الطبعة:

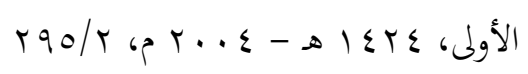

بالجاحظ، عمرو بن بحر بن محبوب، rr أهـ، البيان والتبيين، ، الشهير ، دار ومكتبة الهلال، بيروت. 
بالماوردي، علي بن محمد بن محمد بن حبيب البصري، النكت والعيون، المحقق: السيد ابن عبد المقصود بن عبد

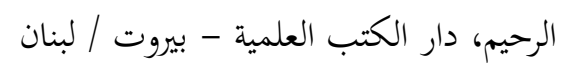
البغدادي، عبد القادر بن عمر، خزانة الأدب ولب لباب لباب لسان العرب، تحقيق وشرح: عبد السلام محمد هارون،

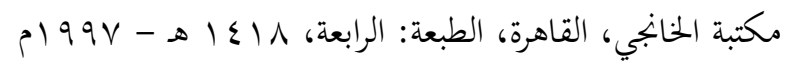

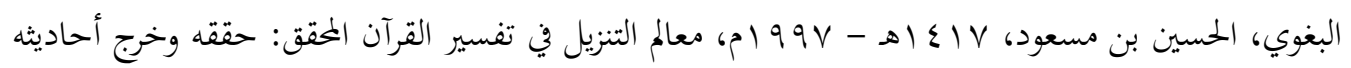
محمد عبد الله النمر - عثمان جمعة ضميرية - سليمان مسلم الحرش، دار طيبة للنشر والتوزيع، الطبعة: الرابعة.

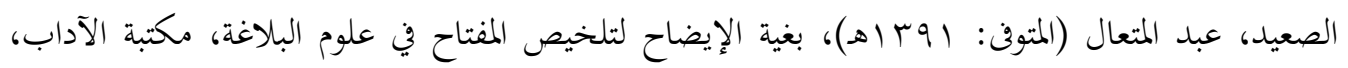

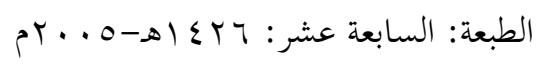

ابن قتيبة الدينوري، أبو محمد عبد الله بن مسلم، الشعر والشعراء دار الحديث، القاهرة: بrع اهـ بيان الحق، محمود بن أبي الحسن، باهر البرهان في معاني مشكلات القرآن، جامعة أم القرى - مكة المكرمة

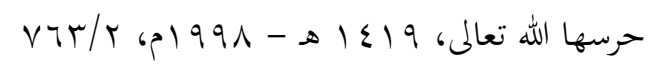

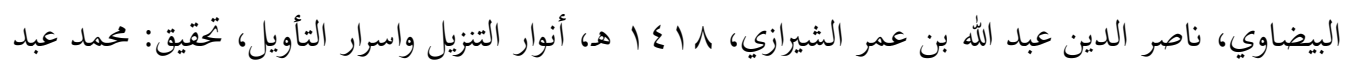

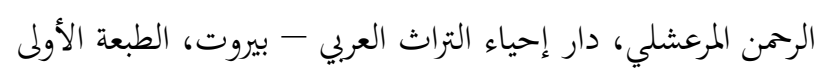
التفتازاني، سعد الدين مسعود بن عمر، المطول شرح تلخيص مفتاح العلوم، تحقيق: عبد الحميد هنداوي، دار الكتب العلمية، لبنان بيروت، الطبعة الثالثة.

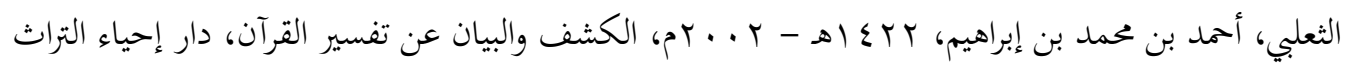
العربي، بيروت - لبنان، الطبعة الأولى.

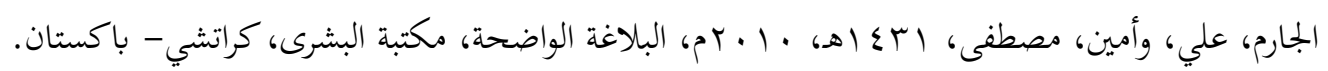

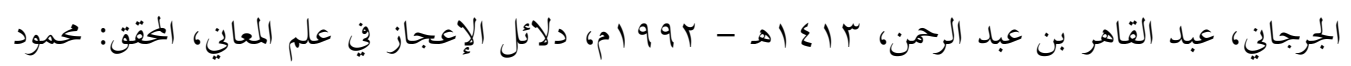
محمد شاكر، مطبعة المدني بالقاهرة - دار المدني بجدة، الطبعة: الثالثة.

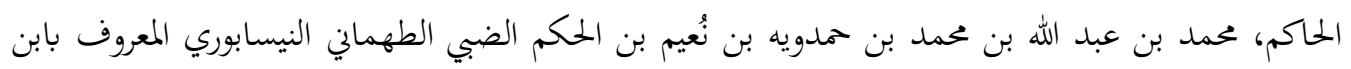
البيع، ال1 اهـ - ـ 99 1م، المستدرك على الصحيحين، تحقيق: مصطفى عبد القادر عطا، دار الكتب العلمية - بيروت، الطبعة: الأولى. الحميرى، نشوان بن سعيد، شمس العلوم ودواء كلام العرب من الكلوم دار الفكر المعاصر (بيروت - لبنان)،

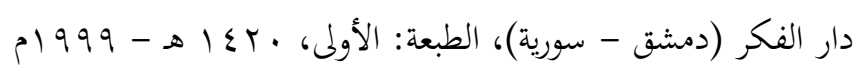

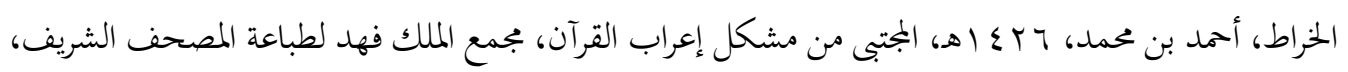
المدينة المنورة. 
I İbrahim Suresinde Haber Üslubunun Belagati/ The Rhetoric of al-Khabar in Surat al-Ibrahim

دراز، صبَّاح عبيد، الأساليب الإنشائية وأسرارها البلاغية في القرآن الكريم، مطبعة الأمانة، الطبعة الأولى:

P) 917 . $181 \leqslant \cdot 7$

درويش، محيي الدين بن أحمد مصطفى، إعراب القرآن وبيانه، دار الإرشاد للشئون الجامعية - حمص - سورية،

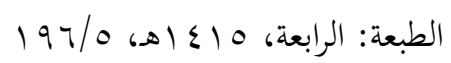

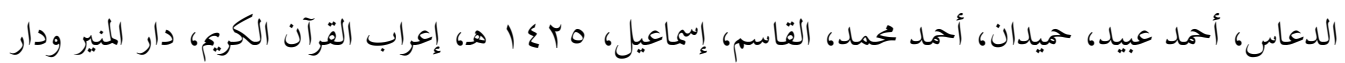
الفارابي - دمشق، الطبعة: الأولى.

الرازي، عبد الله محمد بن عمر بن الحسن بن الحسين، مفاتيح الغيب للرازي، دار إحياء التراث العربي - بيروت، الطبعة الثالثة - . الثب ا هـ

الراغب الأصفهانى، أبو القاسم الحسين بن محمد، · بع 1 هـ - 999 (م، تفسير الراغب الأصفهاني، تحقيق ودراسة: د. محمد عبد العزيز بسيوني، كلية الآداب - جامعة طنطا، الطبعة الأولى:

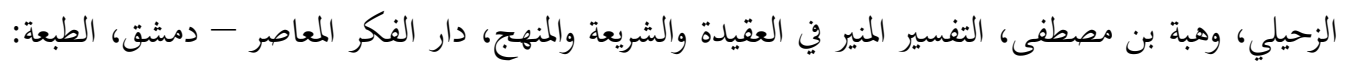
الثانية

الزركلي، خير الدين بن محمود بن محمد بن علي بن فارس، ؟ . . بع، الأعلام، دار العلم للملايين، الطبعة: الخامسة عشر.

الزخشري، أبو القاسم محمود بن عمرو بن أحمد، الكشاف عن حقائق غوامض التنزيل، دار الكتاب العربي بيروت الطبعة: الثالثة - V. مـ الهـ

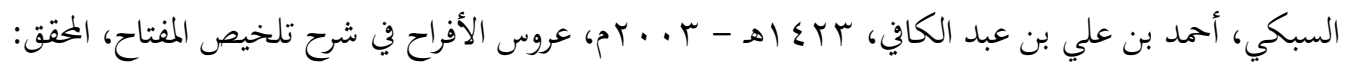
الدكتور عبد الحميد هنداوي، المكتبة العصرية للطباعة والنشر، بيروت - لبنان، الطبعة: الأولى.

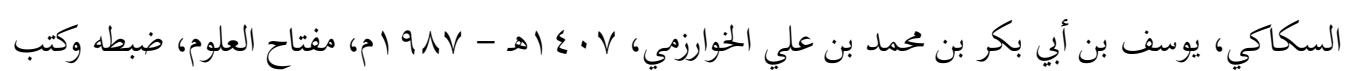
هوامشه وعلق عليه: نعيم زرزور، دار الكتب العلمية، بيروت - لبنان، الطبعة: الثانية.

السمرقندي، أبو الليث نصر بن محمد بن أحمد بن إبراهيم، بحر العلوم، تحقيق: محمد علي العوض، عادل عبد

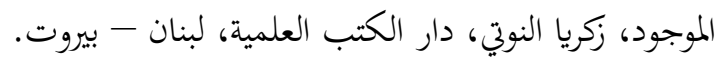

سيد قطب، إبراهيم حسين الشاربي، في ظلال القرآن، دار الشروق - بيروت- القاهرة، الطبعة السابعة عشر - سنرون

$6 \infty) \leqslant 14$ 
الشوكاني، محمد بن علي بن محمد بن عبد الله، فتح القدير، دار ابن كثير، دار الكلم الطيب - دمشق، بيروت،

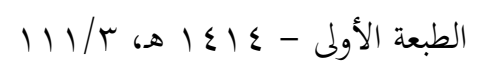

الصافي، محمود بن عبد الرحيم، الجدول في إعراب القرآن الكريم، دار الرشيد، دمشق - مؤسسة الإيمان، بيروت،

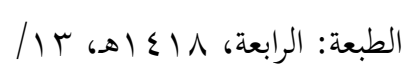

الصيادي، أحمد مطلوب أحمد الناصري الرفاعي، ـ191م، أساليب بلاغية، الفصاحة - البلاغة - المعاني، وكالة المطبوعات - الكويت، الطبعة: الأولى.

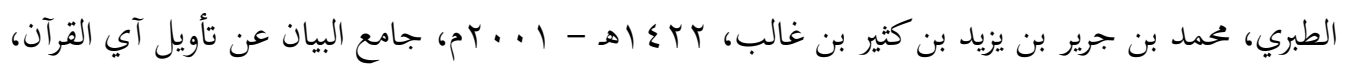
تحقيق: الدكتور عبد الله بن عبد المحسن التركي، دار هجر للطباعة والنشر والتوزيع والإعلان، الطبعة: الأولى.

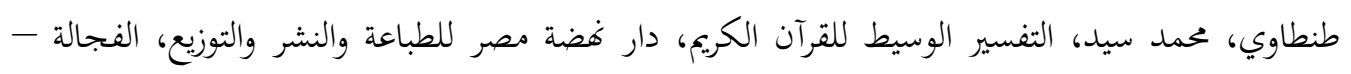
القاهرة

الطبيي، شرف الدين، لطائف التبيان في علم المعاني والبيان، تحقيق: عبد الحميد هنداوي.

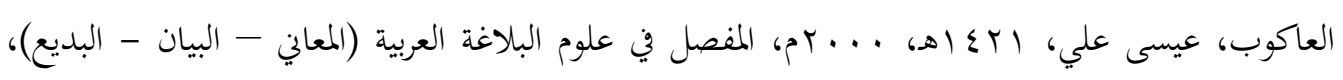

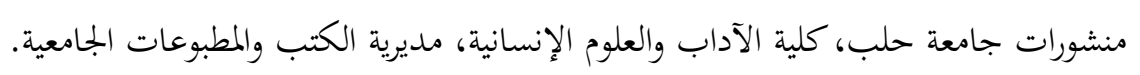
عباس، فضل حسن، البلاغة فنوها وأفناها، دار الفرقان للطباعة والنشر، إربد، الأردن، الطبعة الرابعة: V VI اهـ5199V

عتيق، عبد العزيز، علم المعاني، دار النهضة العربية للطباعة والنشر والتوزيع، بيروت - لبنان، الطبعة: الأولى،

$$
\text { Or G }
$$

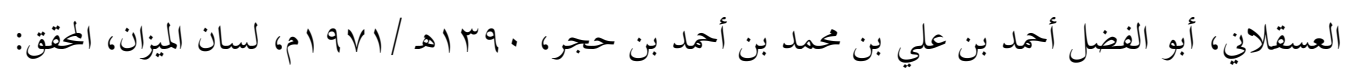

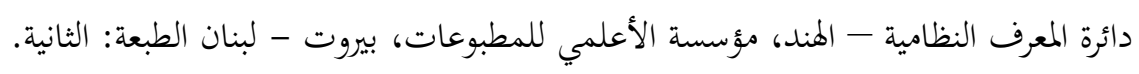

$$
\text { عوني، حامد، المنهاج الواضح للبلاغة، المكتبة الأزهرية للتراث. }
$$

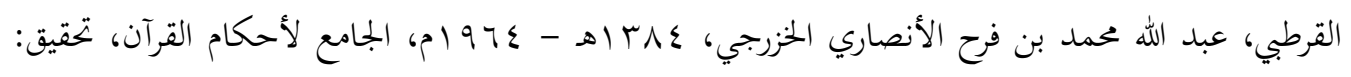

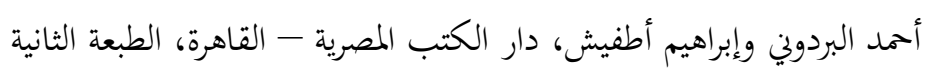

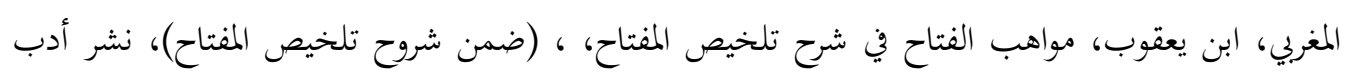

$$
\text { الحوزة، تصوير: دار الكتب العلمية، لبنان -بيروت. }
$$

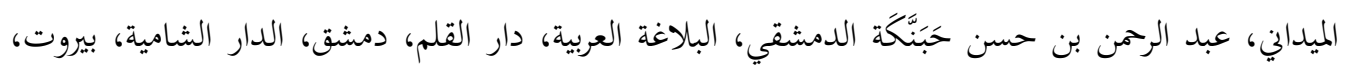

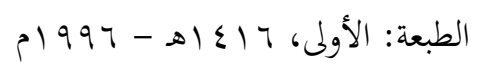

Türkiye İlahiyat Araştırmaları Dergisi Turkey Journal of Theological Studies

[Tiad: 2602-3067]
Cilt / Vol: 2, Sayi/Issue: 1 , 2018 
I İbrahim Suresinde Haber Üslubunun Belagati/ The Rhetoric of al-Khabar in Surat al-Ibrahim

النسفي، عبد الله بن أحمد، 9 1 1 هـ - 191 1 م، مدارك التنزيل وحقائق التأويل، حققه وخرج أحاديثه:

يوسف علي بديوي، دار الكلم الطيب، بيروت، الطبعة الأولى.

النيسابوري، محمود بن أبى الحسن بن الحسين، إيجاز البيان عن معاني القرآن، دار الغرب الإسلامي - بيروت،

$$
\text { الطبعة: الأولى - } 10
$$

الماشمي، أحمد بن إبراهيم بن مصطفى، جواهر البلاغة في المعاني والبيان والبديع، ضبط وتدقيق وتوثيق: د. يوسف الصميلي، المكتبة العصرية، بيروت.

ابن كثير، إسماعيل بن عمر، تفسير القرآن العظيم، دار طيبة للنشر والتوزيع، الطبعة الثانية . بـ اهـ - 999 ام 